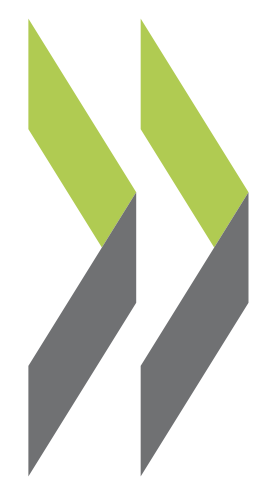

OECD Economics Department Working Papers No. 1068

Labour Market Policies to Promote Growth and Social Cohesion in Korea
Randall S. Jones,

\section{Satoshi Urasawa}




\section{Unclassified}

ECO/WKP(2013)60

Organisation de Coopération et de Développement Économiques

Organisation for Economic Co-operation and Development

27-Jun-2013

ECONOMICS DEPARTMENT

English - Or. English

\section{LABOUR MARKET POLICIES TO PROMOTE GROWTH AND SOCIAL COHESION IN KOREA}

ECONOMICS DEPARTMENT WORKING PAPERS No. 1068

By Randall S. Jones and Satoshi Urasawa

All Economics Department Working Papers are available through OECD's Internet website at http://www.oecd.org/eco/Workingpapers

JT03342496

Complete document available on OLIS in its original format

This document and any map included herein are without prejudice to the status of or sovereignty over any territory, to the delimitation of international frontiers and boundaries and to the name of any territory, city or area. 


\section{ABSTRACT/ RÉSUMÉ \\ Labour market policies to promote growth and social cohesion in Korea}

Labour market reform to improve growth prospects and reduce inequality is a top priority in the face of rapid population ageing and a dualistic labour market. Sustaining output growth requires policies to mitigate the impact of rapid population ageing by increasing labour inputs from under-employed segments of the population. In particular, female labour participation should be encouraged by better work-life balance and increasing the availability of highquality, affordable childcare. More flexible employment and wage systems would increase the age at which older workers leave firms. For young people, improved vocational education at the secondary and tertiary levels would help overcome the labour mismatch and the overemphasis on tertiary education. Labour market dualism creates serious equity concerns, as non-regular workers face significantly lower wages, precarious jobs, less coverage by social security and less training. A comprehensive approach is required to break down dualism, including reduced employment protection for regular workers, alongside improved social insurance coverage and expanded training for non-regular workers.

This Working Paper relates to the 2012 OECD Economic Survey of Korea (www.oecd.org/eco/surveys/Korea).

JEL classification: J11, J3, J5, J7

Keywords: Korea, Korean economy, labour market, dualism, employment protection, non-regular workers, part-time workers, dispatched workers, fixed-term contracts, labour force participation rates, vocational training, female employment, older workers, fertility rates, work-life balance.

\section{Réformer le marché du travail pour stimuler la croissance et améliorer la cohésion sociale en Corée}

La réforme du marché du travail pour améliorer les perspectives de croissance et réduire les inégalités est une priorité absolue face au vieillissement rapide de la population et à un marché du travail dual. Pour soutenir la croissance de la production, les autorités coréennes doivent prendre des mesures pour compenser les effets du vieillissement de la population, en renforçant l'apport de travail des catégories de population sous-employés. Il convient notamment de renforcer le taux d'activité des femmes, en leur assurant des conditions d'emploi permettant de mieux concilier vie professionnelle et vie privée et en améliorant l'offre de services de garde de qualité et à moindre coût. Une plus grande flexibilité des systèmes d'emploi et de rémunération permettrait aux travailleurs âgés de poursuivre leur activité professionnelle. Quant aux jeunes, l'amélioration de la formation professionnelle dans le secondaire et le supérieur contribuerait à résoudre les problèmes d'adéquation entre offre et demande de compétences et de survalorisation de l'enseignement supérieur. Le dualisme engendre de graves problèmes d'équité, car les travailleurs temporaires perçoivent des salaires nettement inférieurs, occupent des emplois précaires, bénéficient d'une couverture sociale plus limitée et d'un moindre accès à la formation. Il faut adopter une approche globale pour briser le dualisme, notamment en réduisant la protection de l'emploi pour les travailleurs réguliers, en améliorant la couverture sociale pour les travailleurs non réguliers et en développant les formations offertes à ces travailleurs.

Ce Document de travail se rapporte à l'Étude économique de l'OCDE de la Corée, 2012 (www.oecd.org/eco/etudes/japon).

Classification JEL : J11, J3, J5, J7

Mots clés: Corée, marché du travail, dualisme, protection de l'emploi, travailleurs non réguliers, travailleurs à temps partiel, travailleurs intérimaires, contrats à durée déterminée, taux de participation au marché du travail, formation professionnelle, activité des femmes, travailleurs âgés, taux de fécondité, équilibre entre travail et vie familiale.

Copyright OECD 2013

Application for permission to reproduce or translate all, or part of, this material should be made to: Head of Publications Service, OECD, 2 rue André-Pascal, 75775 Paris Cedex 16, France. 


\section{TABLE OF CONTENTS}

\section{LABOUR MARKET POLICIES TO PROMOTE GROWTH AND SOCIAL COHESION IN KOREA..... 5}

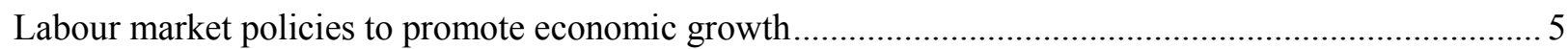

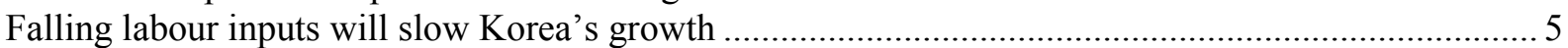

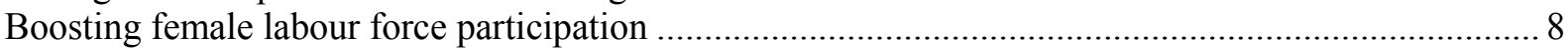

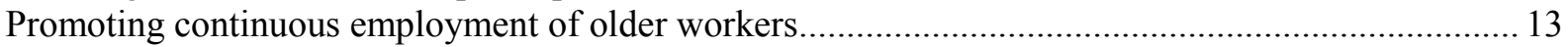

Encouraging labour force participation of discouraged youth............................................................ 17

Labour market policies to break down labour market dualism and promote social cohesion................... 19

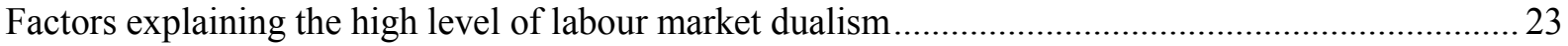

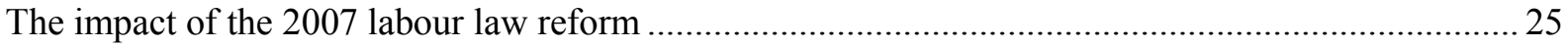

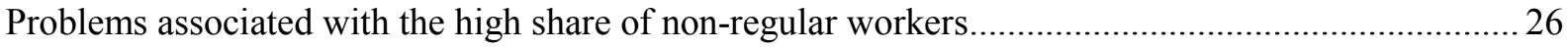

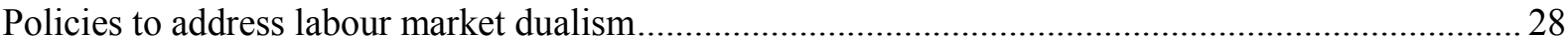

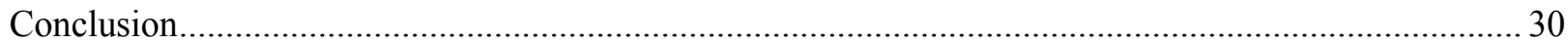

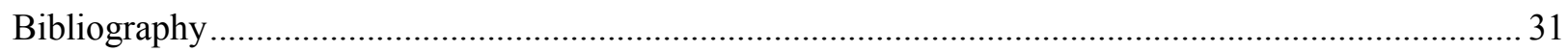

\section{Tables}

1. The desired number of children and obstacles to having them..................................................... 13

2. Reasons given by firms as obstacles to employing older workers................................................. 15

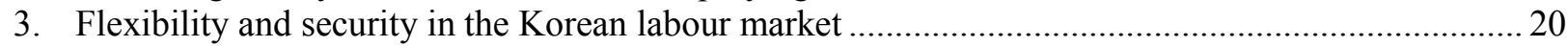

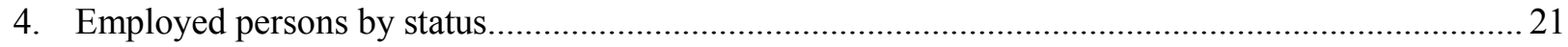

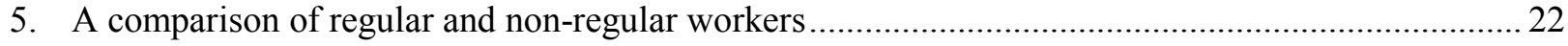

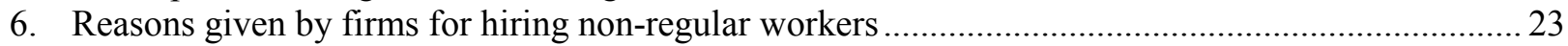

7. Reasons given by non-regular workers for accepting non-regular employment ............................... 24

\section{Figures}

1. Korea's per capita income is converging to the most advanced countries ....................................... 6

2. Population ageing in Korea will be the fastest in the OECD area .................................................... 6

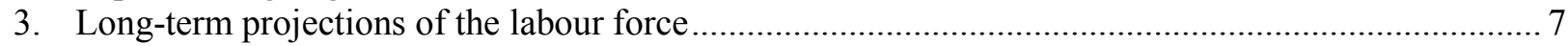

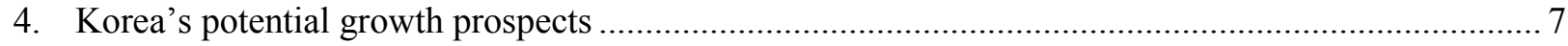

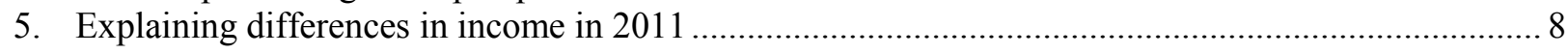

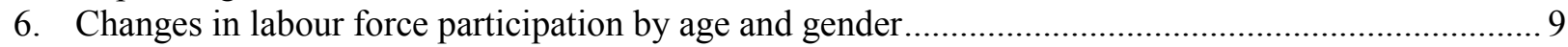

7. Responses of female workers to marriage and childbirth ........................................................... 10

8. Households' share of total spending on educational institutions is high in Korea ............................. 13

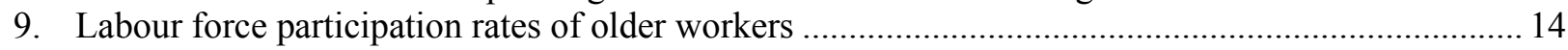

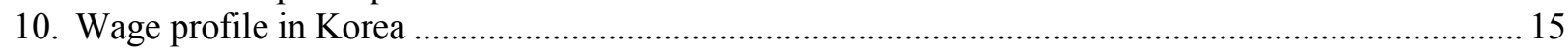

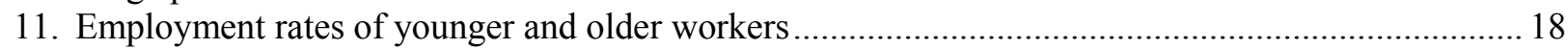

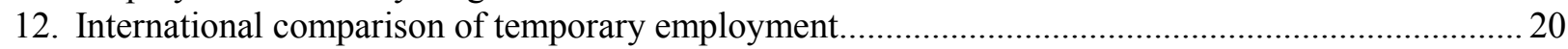

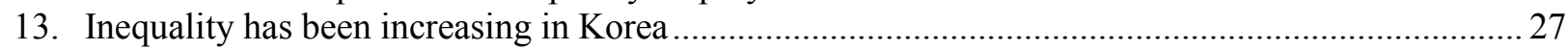

14. Poverty rate among the working-age population in 2006 by employment status.............................. 27

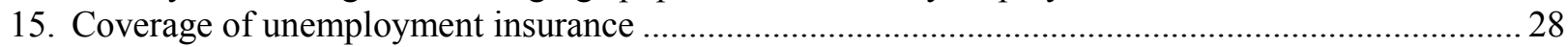




\section{ECO/WKP(2013)60}

\section{Boxes}

Box 1. Second Basic Employment Promotion Plan (2012-16) for the Aged .......................................... 16

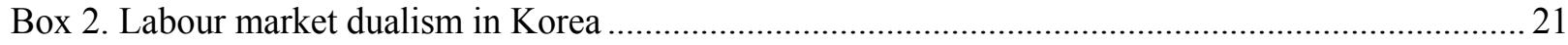

Box 3. Summary of recommendations to enhance growth and social cohesion through labour market

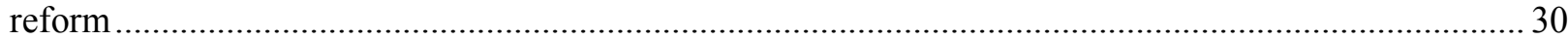

The statistical data for Israel are supplied by and under the responsibility of the relevant Israeli authorities. The use of such data by the OECD is without prejudice to the status of the Golan Heights, East Jerusalem and Israeli settlements in the West Bank under the terms of international law. 
ECO/WKP(2013)60

\title{
LABOUR MARKET POLICIES TO PROMOTE GROWTH AND SOCIAL COHESION IN KOREA
}

\author{
By Randall S. Jones and Satoshi Urasawal
}

1. Despite Korea's rapid economic recovery from the 2008 global crisis, sluggish employment growth prompted the government to launch the "National Employment Strategy 2020" in 2010 (Ministry of Employment and Labour, 2010) to achieve a virtuous cycle of growth, employment and welfare. Labour market issues are now at the top of the national policy agenda. With Korea's working-age population projected to peak in 2016, demographic factors will act as a drag on growth. At the same time, labour market dualism has implications for both growth and equity. The two challenges are linked, as labour market segmentation between regular and non-regular workers discourages some people, particularly women, from working at a time when rapid population ageing makes higher labour force participation a priority. This paper addresses the challenges of raising labour force participation and breaking down labour market dualism. Policy recommendations are summarised in Box 3.

\section{Labour market policies to promote economic growth}

\section{Falling labour inputs will slow Korea's growth}

2. Korea's economic development since 1960 has been among the most rapid ever achieved, boosting per capita income from 12\% of the US level in 1970 to 65\% in 2011 (Figure 1). As Korea has converged towards the high-income countries, its potential per capita growth rate has slowed from around $7 \%$ in 1995 to close to $4 \%$ at present. The fall in Korea's potential growth reflects a deceleration of both productivity and labour inputs. First, the contribution from trend labour productivity has fallen from about five percentage points to three as Korea moved closer to the technology frontier. Second, the contribution from labour inputs has declined from two percentage points to one, as working-age population growth halved (from $1.4 \%$ to $0.7 \%$ ).

3. Looking ahead, Korea faces the most rapid population ageing in the OECD area, reflecting a sharp fall in the fertility rate and a remarkable gain in longevity. The population is expected to peak at about 52 million around 2030 and then drop by $8 \%$ by mid-century. The working-age population, meanwhile, will peak already in 2016 and then fall by more than one quarter by 2050 . Consequently, Korea, currently the fourth-youngest country in the OECD area, will have the second-highest elderly dependency ratio by mid-century (Figure 2). The ratio of the working-age population to the elderly will thus fall from 6.0 in 2010 to 1.3 in 2050, implying that public social spending will pose a heavy burden on a shrinking labour force. Similarly, the total dependency ratio - the number of persons under 20 and over

1. Randall S. Jones is head of the Japan/Korea Desk in the Economics Department of the OECD and Satoshi Urasawa is an economist on that desk. This paper is based on material from the OECD Economic Survey of Korea published in April 2012 under the authority of the Economic and Development Review Committee (EDRC). The authors would like to thank Hyoung-Sun Chung, Andrew Dean, Robert Ford, Vincent Koen, Minwon Lee, Deborah Roseveare, Miho Taguma and Byungseo Yoo for valuable comments on earlier drafts. Special thanks go to Lutécia Daniel for technical assistance and to Nadine Dufour and Pascal Halim for technical preparation. 
65 as a share of the working-age population - will double from $52 \%$ in 2010 to $105 \%$ in 2050 , the third highest in the OECD area.

Figure 1. Korea's per capita income is converging to the most advanced countries ${ }^{1}$

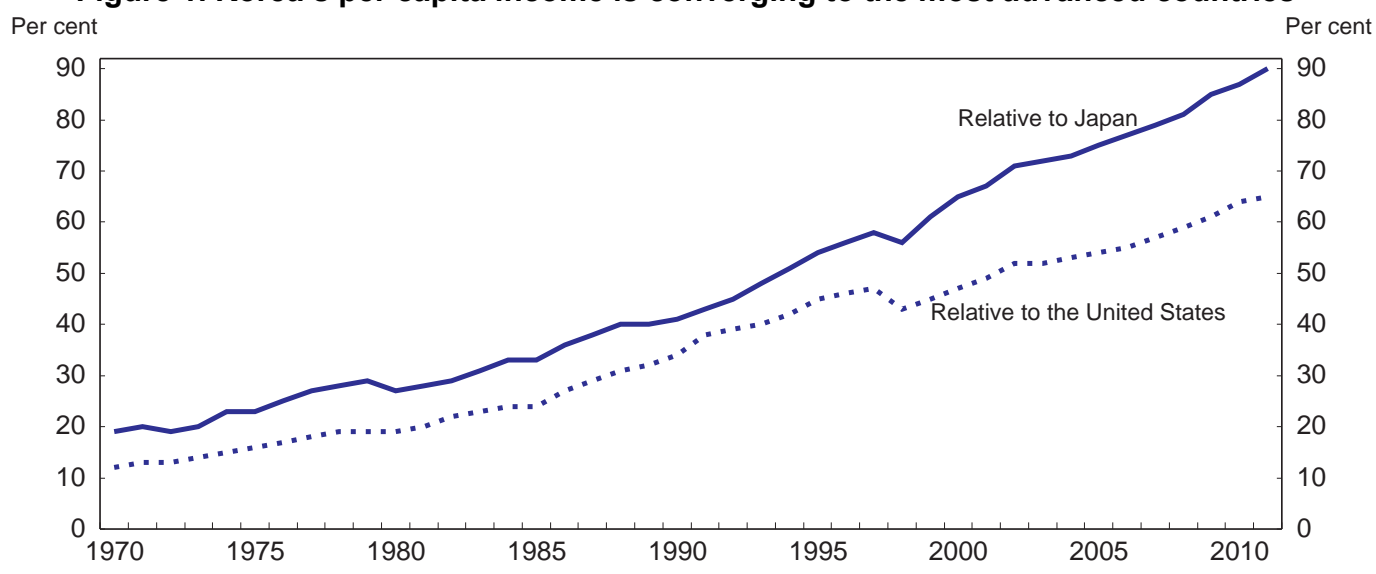

1. In volume, using 2005 purchasing power parity exchange rates.

Source: OECD (2013), Going for Growth 2013.

4. Rapid population ageing implies a substantial fall in the labour force. If participation rates were to remain at their current levels for each age group, the labour force would peak at 27.2 million in 2022 and then fall by $21 \%$, to around 21.5 million, by mid-century (Figure 3). By that point, there would be only 1.2 persons in the labour force per elderly person, compared with 4.5 in 2010, imposing a heavy burden on workers. The Korea Development Institute estimates that Korea's potential growth rate will fall to $1.7 \%$ during the 2030s, as the contribution from labour inputs turns negative (Figure 4). In per capita income terms, the fall in potential will be more gradual - from $4.0 \%$ during the current decade to $2.2 \%$ in the 2030 s - given the decline in population.

Figure 2. Population ageing in Korea will be the fastest in the OECD area ${ }^{1}$

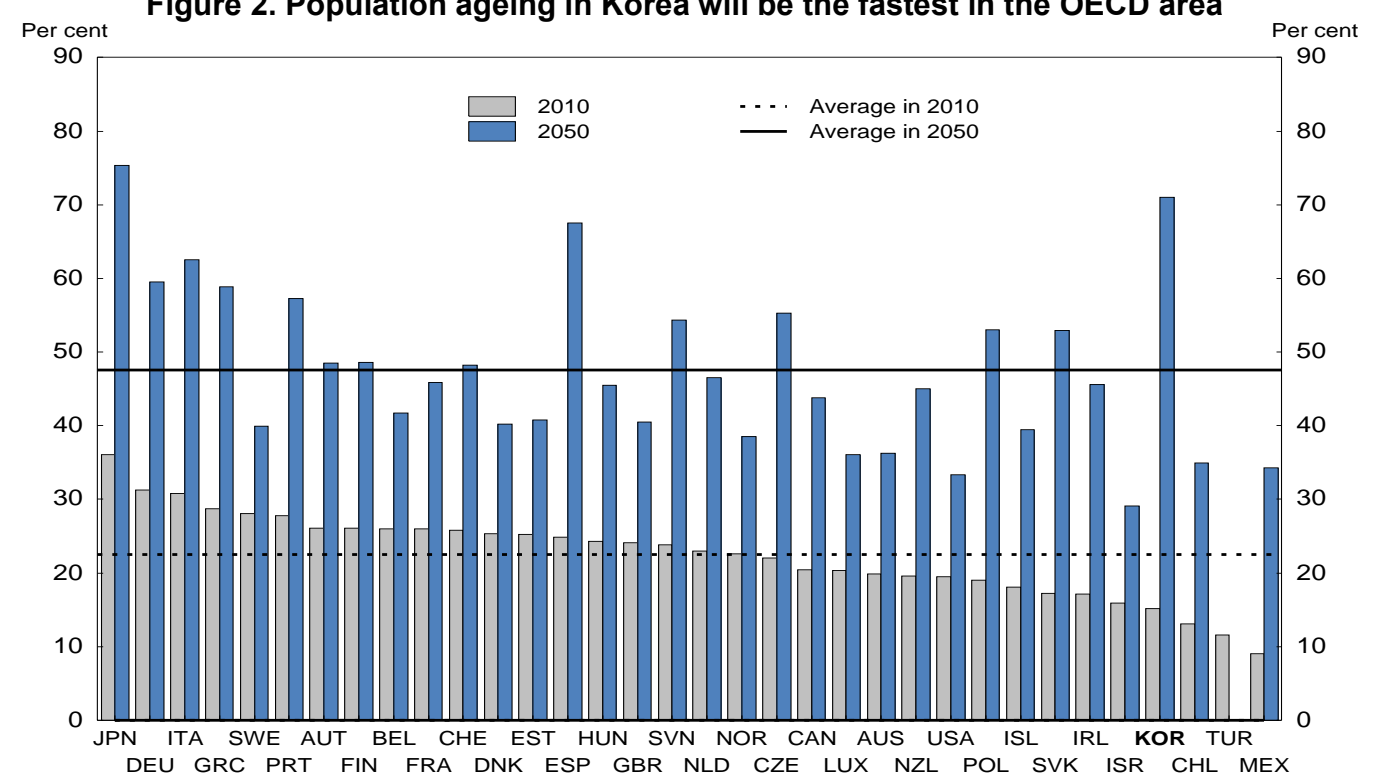

1. The elderly dependency ratio shown in this figure is defined as the over-65 population as a share of the 20-to-64 population.

Source: Statistics Korea, Population Projection for Korea (2011 version) and OECD Demography and Population Database. 
Figure 3. Long-term projections of the labour force

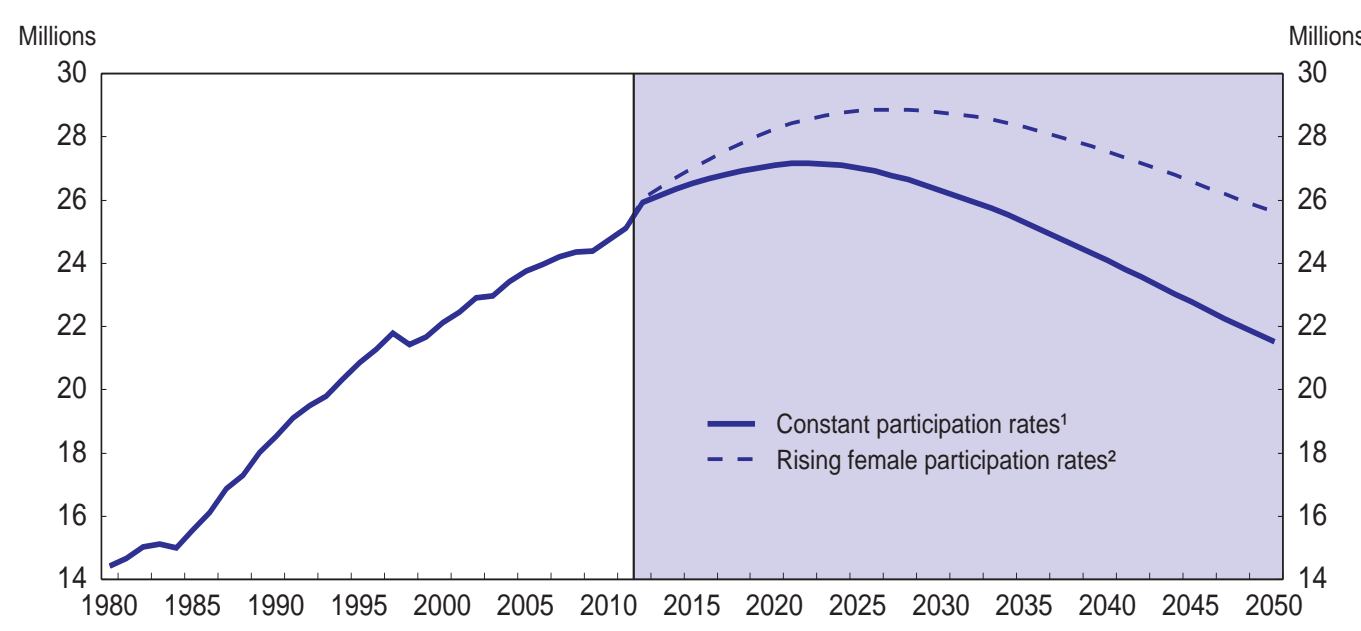

1. The participation rates for men and women are assumed to remain at their current levels for each age group.

2. Female participation rates are assumed to reach current male rates in each age group by 2050.

Source: Statistics Korea, Population Projection for Korea (2011) and Economically Active Population Survey, and OECD calculations.

5. Falling labour inputs will also slow Korea's convergence to the income levels to the highest income countries. As noted above, Korea's GDP per capita has risen to two-thirds of the US level. The remaining gap can be divided into labour inputs (Figure 5, the middle column) and labour productivity (the right-hand column). Labour inputs, relative to population, are by far the largest in the OECD area, reflecting long working hours that are $25 \%$ above the OECD average. The gap is likely to narrow quickly as the working-age population begins falling from 2017 and as working hours, which have been declining at a $1.5 \%$ annual rate since 2000 , continue to drop. Measures to mitigate falling labour inputs are therefore important to sustain Korea's convergence to the highest-income countries. As noted in the National Employment Strategy 2020, making greater use of vulnerable workers, notably women, the elderly and youth, is a priority. At the same time, there is significant scope for productivity gains, as Korea's labour productivity per hour of work is only about half of the US level.

Figure 4. Korea's potential growth prospects Annual average percentage rate

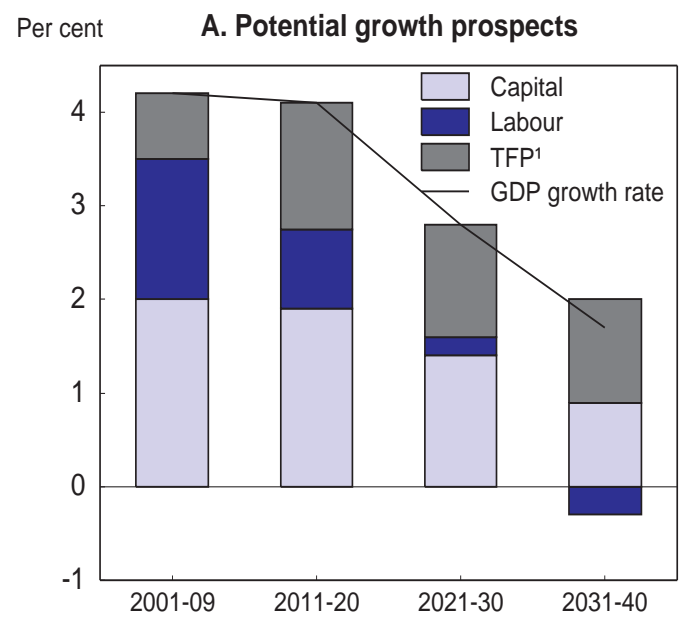

B. Potential per capita growth prospects Per cent

1. Total factor productivity.

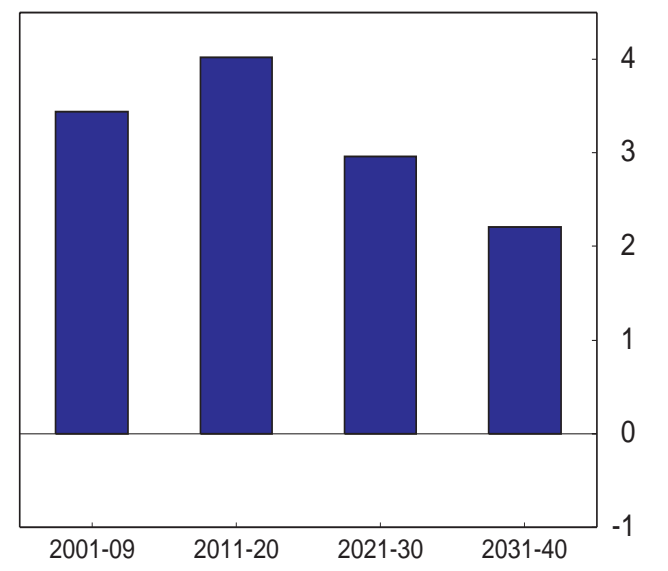

Source: Korea Development Institute. 
Figure 5. Explaining differences in income in 2011

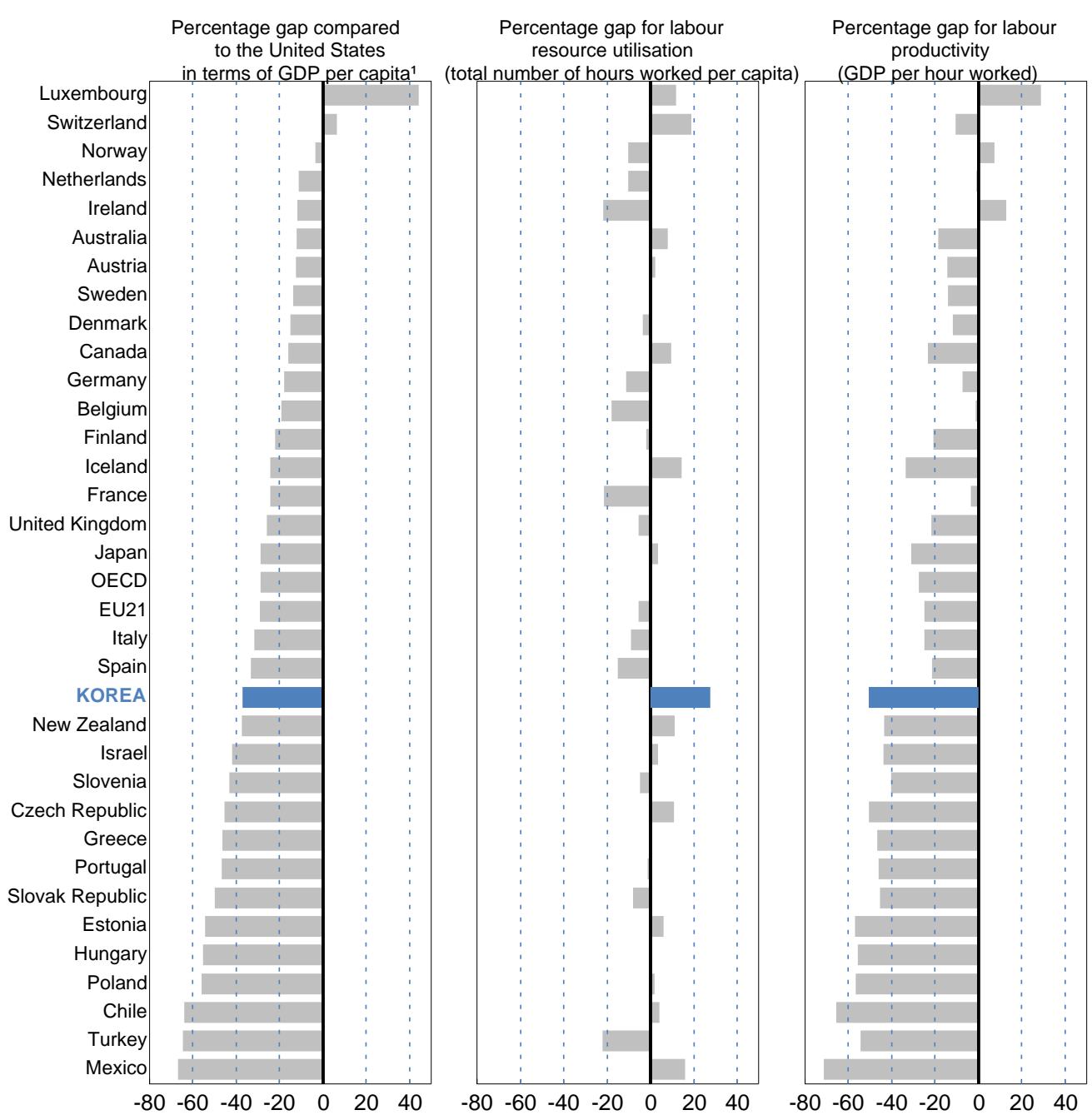

1. Using 2011 PPP exchange rates.

Source: OECD (2013), Going for Growth 2013.

\section{Boosting female labour force participation}

6. As noted, if participation rates were to remain at their current levels for each age group by gender, the labour force would fall by one-fifth relative to its 2022 peak by 2050 (Figure 3). However, if the female participation rate were to converge to the current level for males for each age group by 2050 , the labour force would only fall to around 25.6 million, $19 \%$ higher than in the case of unchanged participation rates.

\section{Factors keeping down the female participation rate}

7. Women's participation rate was $54.5 \%$ of the working-age population in 2010, compared to an OECD average of $61.8 \%$ and more than $70 \%$ in some advanced countries. The government has set a target of boosting the rate to $60 \%$ by 2014 . Although the participation rate of prime-age women (the 25-to-54-age group) increased from 54\% in 1990 to $62 \%$ in 2010, it was still the third lowest in the OECD area. The low rate reflects the withdrawal of a majority of women at the time of marriage or childbirth, although most return later, resulting in an M-shaped pattern not found for Korean men or for women in the OECD area as 
a whole (Figure 6). The withdrawal of women is due to the challenge of combining employment with caring for a family. According to a 2010 government survey, $53 \%$ of women responded that "family responsibilities" were the primary obstacle to employment, followed by their children's schooling (19\%) and childcare (14\%). The tradition of long working hours in Korea (see below) makes it difficult for both parents to work as regular workers. Consequently, $57 \%$ of married women are not in the labour force and instead bear most of the family responsibilities.

Figure 6. Changes in labour force participation by age and gender

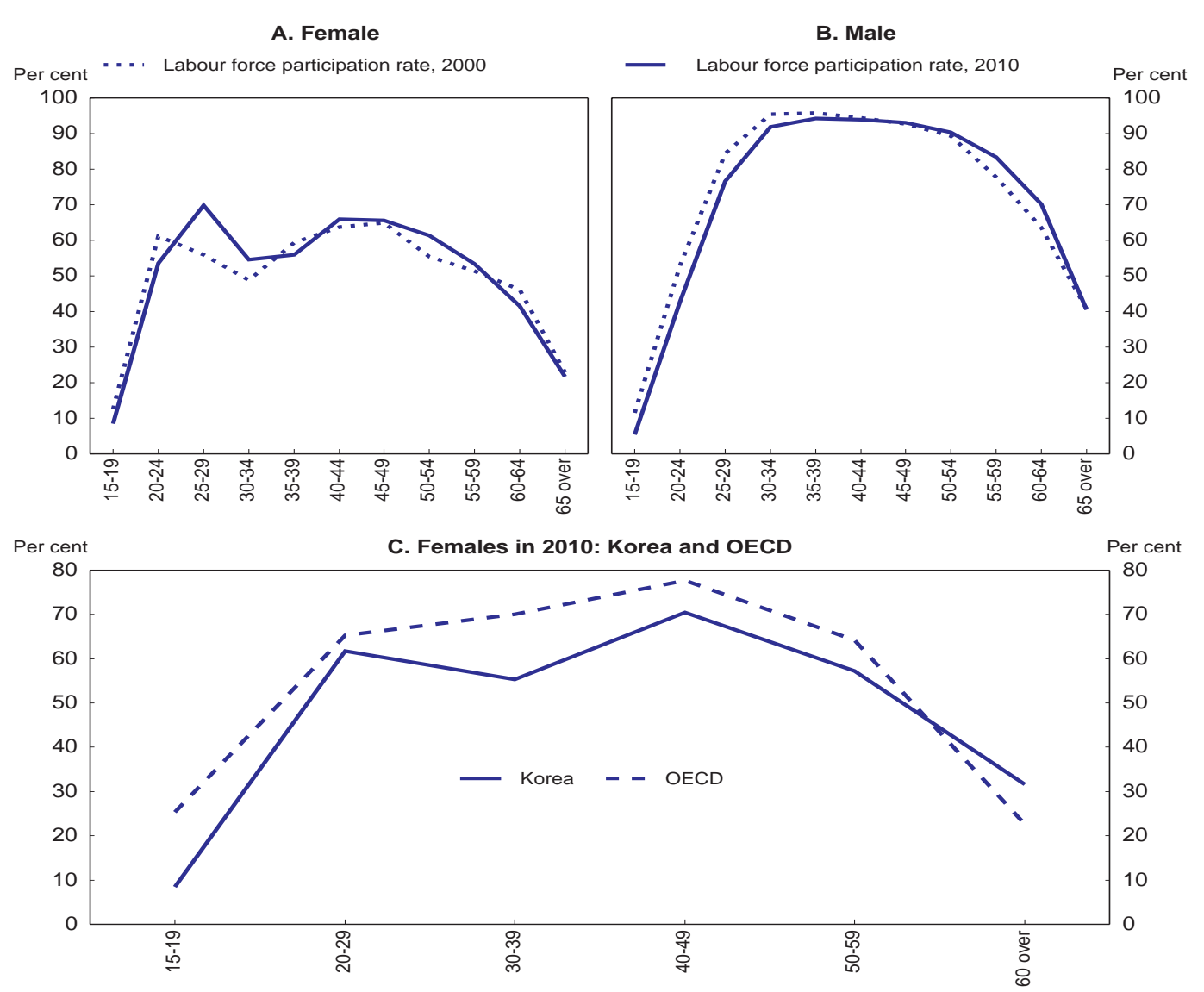

Source: OECD Employment Outlook Database.

8. $\quad$ Another study (Figure 7) found that:

- In $2007,58 \%$ of female workers withdrew from the labour force when they marry, with the figure much higher for employees than for the self-employed or family workers. Another $27 \%$ leave at the time of the birth of their first child and 10\% when a second child is born (Panel A).

- Women with higher educational attainment were less likely to withdraw following marriage than those with a lower educational attainment, reflecting their higher opportunity cost of not working. However, they are more likely to withdraw following the birth of a child (Panel B).

- A large share of women who were employees prior to interrupting their careers for marriage and childbirth return to the labour force as self-employed and unpaid family workers. Indeed, the share of women working as employees fell significantly from $87 \%$ prior to marriage to $27 \%$ after 
their second child (Panel C). Moreover, many of those who are employees work as lower-paid non-regular workers.

- The share of women who returned to work after their first child falls for the first four years, perhaps due in part to the birth of an additional child. The rate of return to the labour force gradually rises as children enter school and reaches $46 \%$ after nine years (Panel D).

Figure 7. Responses of female workers to marriage and childbirth ${ }^{1}$
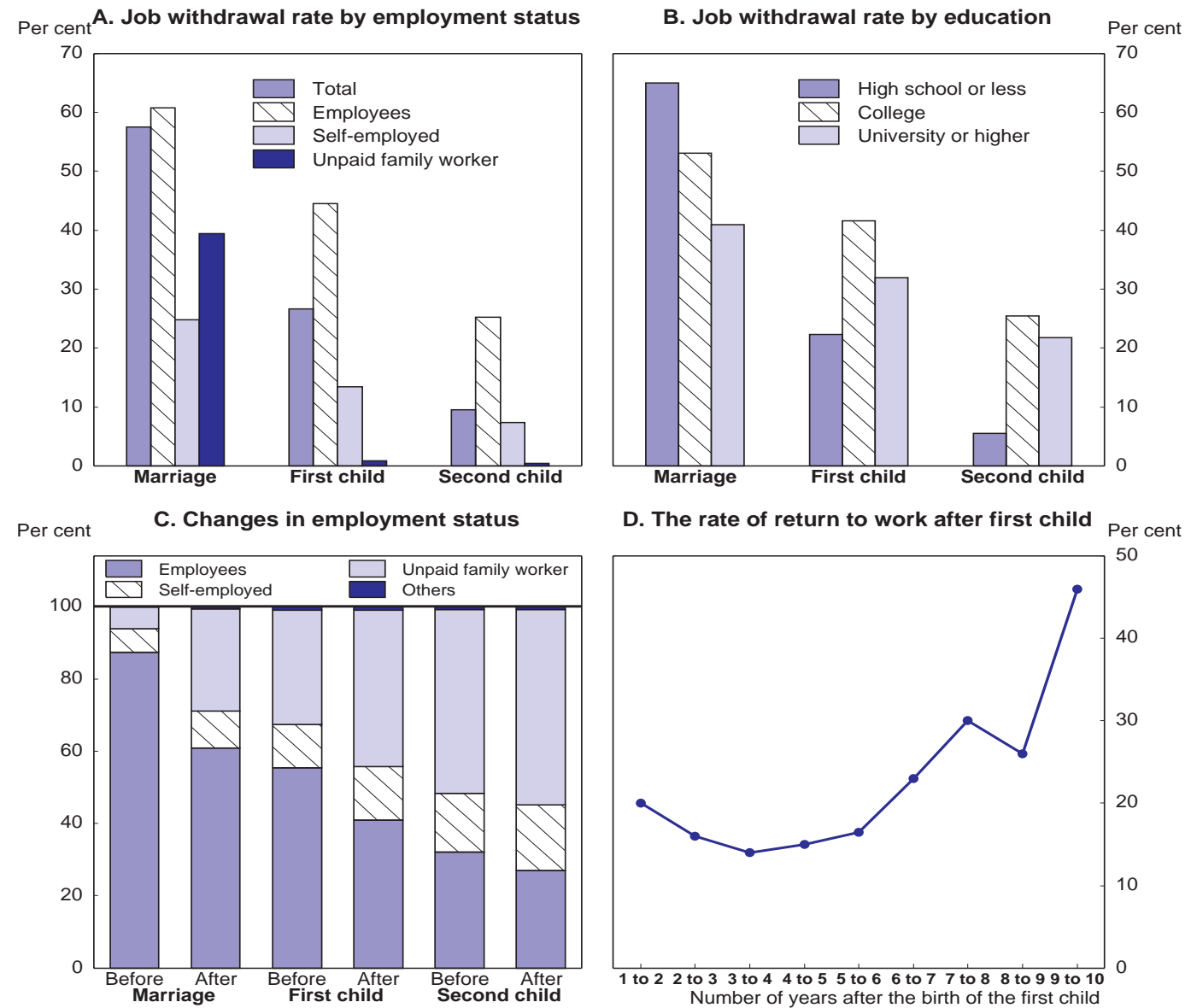

D. The rate of return to work after first child Per cent

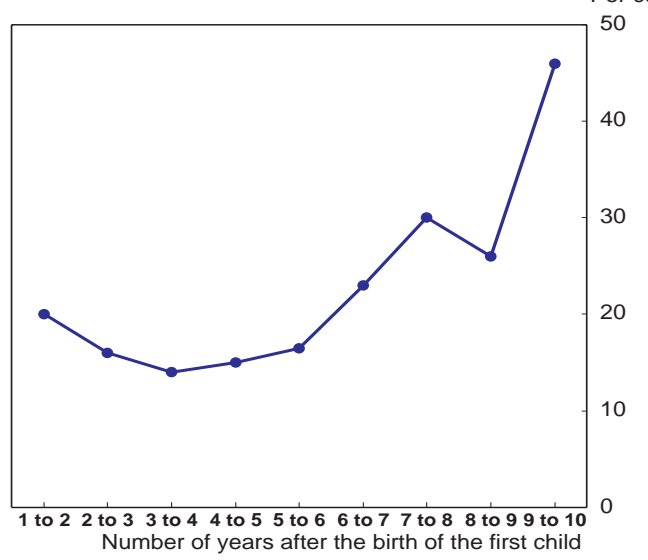

1.

The 2007 survey samples for marriage, birth of a first child and a second child are not necessarily identical.

Source: Kim (2011).

\section{Policies to boost the labour force participation of women}

9. Realising the $60 \%$ target for female participation among the working-age population by 2014 will require a number of reforms, although it is difficult for the government to change business practices and social customs. Nevertheless, it has taken steps to alleviate the burden of bearing and caring for children and to create more family-friendly workplaces, based on the recommendations by the Korean Committee on Low Fertility and Population Ageing Policy in 2006:

i. $\quad$ Expanding investment in public childcare, while introducing a subsidy for private facilities;

ii. Encouraging flexible working schedules, including shorter hours for parents with childcare responsibilities; 
iii. Lengthening maternity leave to 90 days for women employed at small and medium-sized enterprises (SMEs), with the cost covered by the Employment Insurance System (EIS);

iv. Raising the childcare leave benefit and easing the conditions attached to it. $^{2}$

10. These measures were followed by the 2011 revision of the Equal Employment Opportunity and Work-Family Balance Assistance law, which allows parents with children under age six to request shorter working hours. ${ }^{3}$ The government also encouraged more fixed-term and "dispatched workers" (workers from temporary worker agencies) to take childcare leave by excluding the leave time from the legal time limits on their length of employment. Better work-life balance would also benefit firms by reducing the turnover of skilled workers, leading to higher productivity (Kim and Hwang, 2009).

11. The take-up rate for maternity leave is now estimated at $63 \%$ for regular employees and $37 \%$ for non-regular workers. By 2010, the number of women taking maternity leave had increased to around 75000 . However, the average length was 13 weeks in 2008, below the OECD average of 19 weeks. Further extending the length of maternity leave beyond 90 days and expanding the coverage of the EIS, which plays a major role in financing it, would encourage female workers to remain in the labour force at the time of childbirth. One study found that around five months is the optimal length from a labour supply perspective (Jaumotte, 2003). Longer maternity leave should be accompanied by longer parental leave, which averages 46 weeks, well below the OECD average of 72 weeks. Moreover, the full-time paid equivalent is ten weeks, only half of the OECD average, suggesting a need to make the benefit more generous. The number of fathers taking childcare leave surpassed 1000 in 2011 for the first time, but still accounts for only $2 \%$ of parents taking the leave. The limited take-up reflects fathers' concern that it would have negative effects on their career and relationships with colleagues (OECD, 2011). Reserving a part of the parental leave for the exclusive use of fathers would increase their take-up of parental leave.

12. In addition to maternity and parental leave, reducing working hours is a priority to improve worklife balance. The tradition of long working hours stems in part from heavy use of overtime, encouraged by a large overtime premium and low marginal income tax rates, and unused annual leave. Compared to other countries, Korean workers tend to favour working longer hours and earning more (Choi et al., 2012). As for firms, they prefer to meet increased demand through longer hours rather than by expanding the number of employees, given the fixed costs of hiring and the employment protection that makes it expensive to dismiss unnecessary workers (Kim and Hwang, 2009). In 2007, 87\% of men (the fifth highest in the OECD area) and $77 \%$ of women (the seventh highest) worked more than 40 hours per week (OECD, 2011). The emphasis should shift from long working hours to productivity, which would also help expand domestic demand. Following the gradual introduction of the 40-hour workweek, beginning with companies with more than 1000 workers in 2004, average annual working hours fell by $8 \%$ to 2193 in 2010. The decline in working hours for the self-employed, who are not subject to limits on hours, followed a similar pattern, suggesting that shorter hours reflect social preferences.

13. Nevertheless, annual working time remains the longest in the OECD area at $25 \%$ above the average of 1749 hours in 2010. The government goal to cut working time to 1800 hours would require a number of measures. First, strictly enforcing the 40-hour workweek, as well as the 12-hour limit on weekly overtime, would reduce working time. In $2011,15 \%$ of employees worked more than 53 hours per week,

2. In 2010, eligibility was expanded from an employee whose children are age three or younger to age six or younger. Each parent can take up to one year of leave. A worker taking parental leave receives $40 \%$ of his or her salary, of which $15 \%$ is paid six months after the return to work.

3. According to the law, "the employer will be required to allow that worker to work shorter hours as long as there is no special managerial reason". In addition, it made the three-day unpaid paternity leave paid, with the possibility of an additional two days of unpaid leave. 
thus violating the labour code. Long working hours are more prevalent at smaller companies. In 2010, working time at companies with between five and nine employees was $7 \%$ longer than at those with more than 300 employees (KEF, 2011). Second, the legal exemptions to working time limits for certain professions, such as hospital workers, could be narrowed. Third, the 40-hour workweek, which was extended in July 2011 to all firms with more than five workers, could be extended to firms with fewer than five workers. Fourth, the government should encourage the use of annual leave. While firms granted 25 days on average, workers used only 13, with the take-up rate lower at larger companies (KEF, 2011).

14. To boost female participation, the government introduced a bill in 2011 to promote the employment of part-time workers, which accounted for only $18 \%$ of female employment in 2011 , well below the OECD average of $26 \%$ (OECD, 2012d). As part of this effort, it is promoting flex-time, which allows flexibility in arrival and departure times from work. However, part-time work is classified as nonregular employment, which brings a number of disadvantages, including lower hourly wages, thus weakening the incentives for female part-time employment, particularly for highly-educated women with a high reservation wage. ${ }^{4}$ This underscores the importance of reducing the disadvantages of non-regular employment (see below). In addition, firms resist part-time employment as it breaks up the continuity of work, complicates personnel management and expands the need for training. According to the Korea Employers Federation (2011), the "majority view is that part-time regular employment is not appropriate for the Korean labour market".

15. Another factor discouraging female employment is the gender gap in earnings, despite government efforts, such as the 1997 Equal Opportunity Law, to eliminate discrimination against women. A 2006 law required both public and private firms with more than 1000 workers to draw up an action plan and make voluntary efforts to promote gender equality. This initiative was expanded to firms with more than 500 workers in March 2008. Nevertheless, in 2010, female workers were paid only $60 \%$ as much as male workers, virtually unchanged from 1996 (OECD, 2011). The gender wage gap, the largest in the OECD area, reflects the large share of women engaged in non-regular employment with low wages, as well as the low proportion in management positions. Indeed, women accounted for only $8 \%$ of managers in Korea between 2007 and 2009, well below the OECD average of 29\%. It is important to create better job opportunities for women that would attract them to the labour market, in part by reducing dualism and expanding the weight of performance in setting wages, thereby narrowing the gender wage gap. In short, reforms are needed to offer women the hours, jobs, wages and careers that would encourage them to work.

16. It is also important to expand the availability of affordable, high-quality childcare, which women cite as a major obstacle to employment (see the 2012 OECD Economic Survey of Korea). In addition to boosting female participation, it would help achieve the government's goal of boosting the fertility rate. Indeed, OECD studies have found a positive relationship between childcare and female employment (OECD, 2007b) and between childcare and the fertility rate (D'Addio and Mira d'Ercole, 2005). Boosting the fertility rate also depends on reducing the burden of education. According to a survey of parents, the desired number of children is 1.81 , well above the birth rate of 1.15 in 2009.5 The burden of education is the major factor for having fewer children than their desired number; $57.9 \%$ cited education costs, $17.3 \%$ the cost of childcare and kindergarten and $9.8 \%$ the cost of university (Table 1). Households accounted for $27 \%$ of spending on educational institutions in 2009, the second highest in the OECD area, even before taking account of large outlays for private tutoring (Figure 8). In comparison, households' share was only $13 \%$ in the OECD area.

4. The Federation of Korea Trade Unions complains that many part-time workers, who typically work six hours a day, are forced to work eight hours with no overtime payments.

5. Hyundai Research Institute (2010). According to a survey taken in the mid-2000s, the average number of children desired by Korean women between the ages of 15 and 54 was 2.2 . 
Table 1. The desired number of children and obstacles to having them In per cent ${ }^{1}$

A. Desired number of children

\begin{tabular}{|c|c|c|c|c|c|c|c|}
\hline & & Total & Single & \multicolumn{4}{|c|}{ Married } \\
\hline \multirow[b]{2}{*}{ Do not want children } & & \multirow[b]{2}{*}{4.3} & \multirow[b]{2}{*}{6.2} & Sub-total & No children & 1 child & 2 children \\
\hline & & & & 1.4 & 5.5 & 0.0 & 0.0 \\
\hline & 1 & 24.0 & 20.9 & 29.3 & 34.5 & 47.8 & 0.0 \\
\hline Want children (number) & 2 & 58.2 & 59.1 & 56.7 & 47.3 & 47.8 & 75.4 \\
\hline & 3 & 13.5 & 13.8 & 12.9 & 12.7 & 4.3 & 24.6 \\
\hline
\end{tabular}

B. The most serious obstacles to having children

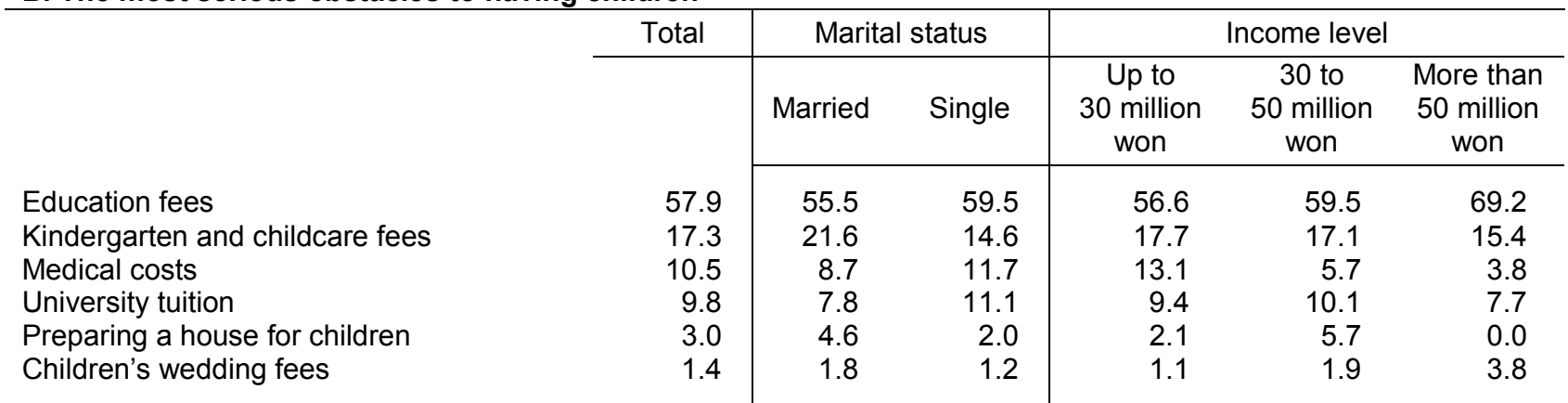

1. $\quad$ Based on a survey of 557 adults.

Source: Hyundai Research Institute (2010).

Figure 8. Households' share of total spending on educational institutions is high in Korea ${ }^{1}$

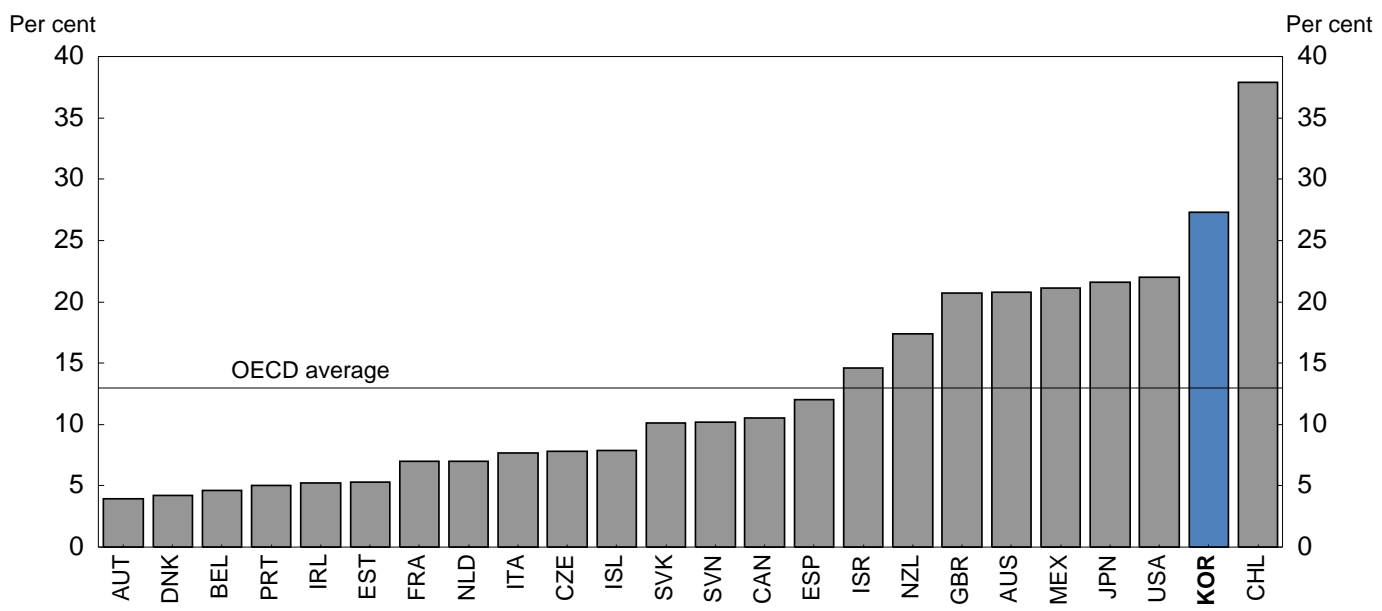

1. Spending in 2009 , excluding outlays on private, after-school tutoring.

Source: OECD (2012c), Education at a Glance 2012.

\section{Promoting continuous employment of older workers}

17. Koreans tend to have long working lives, but, paradoxically, also face early retirement from firms, which is increasingly inappropriate in the context of rapid ageing. The labour force participation rate for the 55-to-64-age group was $63.7 \%$ in 2011 , above the OECD average of $57.8 \%$, reflecting the still-low coverage and small pensions from the National Pension Scheme (NPS). Moreover, the company pension system introduced in 2005 is also still in an early stage of development. The participation rate falls from a peak of $80 \%$ in the 45 -to- 49 group to $57 \%$ of the 60 -to-64 group, with little change since 2000 (Figure 9). 
Sustaining a high participation rate - or even increasing it to the highest levels in the OECD area - will be a challenge as pension systems develop.

Figure 9. Labour force participation rates for older workers

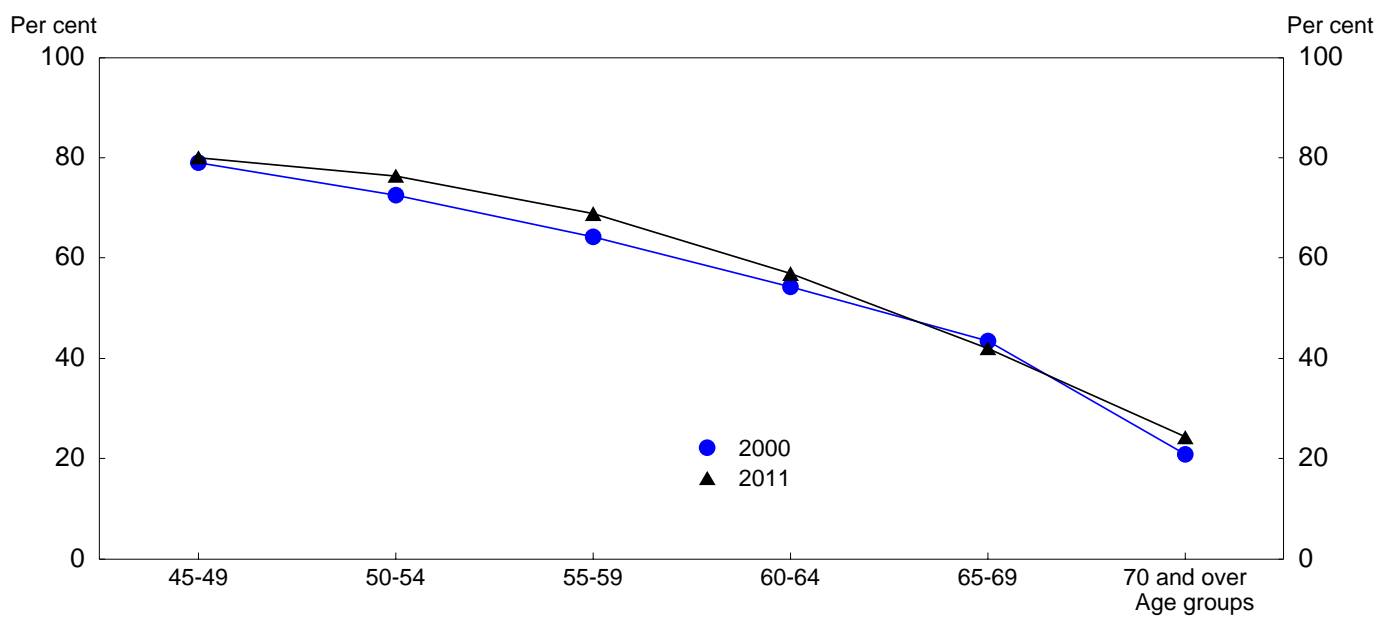

Source: OECD Employment Outlook Database.

18. However, most workers leave firms at a relatively young age, as the mandatory retirement age set by firms in 2010 averaged 57 years and 95\% of firms with more than 300 workers set the age below 60 . Moreover, the length of tenure in firms peaks around age 50, as many workers leave prior to the mandatory retirement age. Many firms force workers to retire before the mandatory age, either through incentives (bonuses) or penalties (shifting workers to undesirable jobs) (Klassen, 2011). A survey that asked firms which factors discourage the employment of older workers reported that the most important reasons were related to their ability, such as "low adaptability to change" (57.3\% of firms), "lower work ability and capacity" (44.8\%) and "difficulty in assigning to posts" (39.7\%) (Table 2). Older workers tend to lack the skills needed in an increasingly knowledge-based economy, reflecting their low educational attainment compared to younger workers.

19. In addition, high wage costs due to the seniority-based wage system were cited by $43.1 \%$ of firms. Indeed, a worker with more than 25 years of tenure in a firm earns almost two and a half times more than a newly-hired employee (Figure 10). Firms agree to steep seniority-based wage profiles on the condition that they can force older workers to retire when wages surpass productivity. Finally, the cultural emphasis on age and seniority make it difficult for older persons to be supervised by someone younger, leading to "up-or-out" personnel practices. The difficulty of older workers in accepting instructions is cited by $19.9 \%$ of firms.

20. The departure of workers from firms at a relatively young age is a waste of human capital. According to the Korea Longitudinal Study of Ageing, 37\% of workers became unemployed once reaching the mandatory retirement age. Among those who continue to work, only $38 \%$ remained as regular workers, while $10 \%$ moved into non-regular employment. Another $13 \%$ became self-employed, primarily in services with low productivity. Early departure also disrupts the NPS, as the unemployed, self-employed or non-regular workers tend to not contribute to the public pension system. In short, the current system benefits firms at the expense of individuals and the government. Extending the employment of older workers would enhance Korea's growth potential, reduce excess labour in low productivity selfemployment in services and promote the long-run sustainability of the public pension system. 
Table 2. Reasons given by firms as obstacles to employing older workers

In $2008^{1}$

\begin{tabular}{lc}
\hline Reasons & Per cent \\
\hline Low adaptability to change & 57.3 \\
Lower work ability and capacity & 44.8 \\
High wages relative to productivity & 43.1 \\
Difficulty in assigning to posts & 39.7 \\
Unable to perform difficult tasks & 32.9 \\
Little motivation or enthusiasm for new work & 25.8 \\
Difficulty in accepting instructions & 19.9 \\
Frequent accidents & 8.2 \\
Lack of ability to co-operate with other workers & 6.3 \\
\hline
\end{tabular}

1. The survey included 648 firms. Firms were allowed to give three answers.

Source: Korea Labor Institute, Survey on Firms Implementing the Wage Peak Compensation Scheme 2008.

\section{Government policies to promote better use of older workers}

21. The government's 2006 five-year plan to foster the employment of older persons included a number of initiatives: $i$ ) encouraging firms to raise their mandatory retirement age; $i i)$ supporting the reemployment of older persons who left their jobs involuntarily because of mandatory retirement; and iii) promoting friendly working conditions for older people. The government provides wage subsidies to firms that guarantee employment until their retirement age, increase their retirement age or offer reemployment programmes to retirees. The government also offers subsidies for firms adopting the "wagepeak system", which allows workers to remain at the firm beyond the mandatory retirement age, although at a wage below that based on seniority. In addition, it introduced a law in 2010 to prohibit age discrimination in recruitment and employment.

Figure 10. Wage profile in Korea ${ }^{1}$

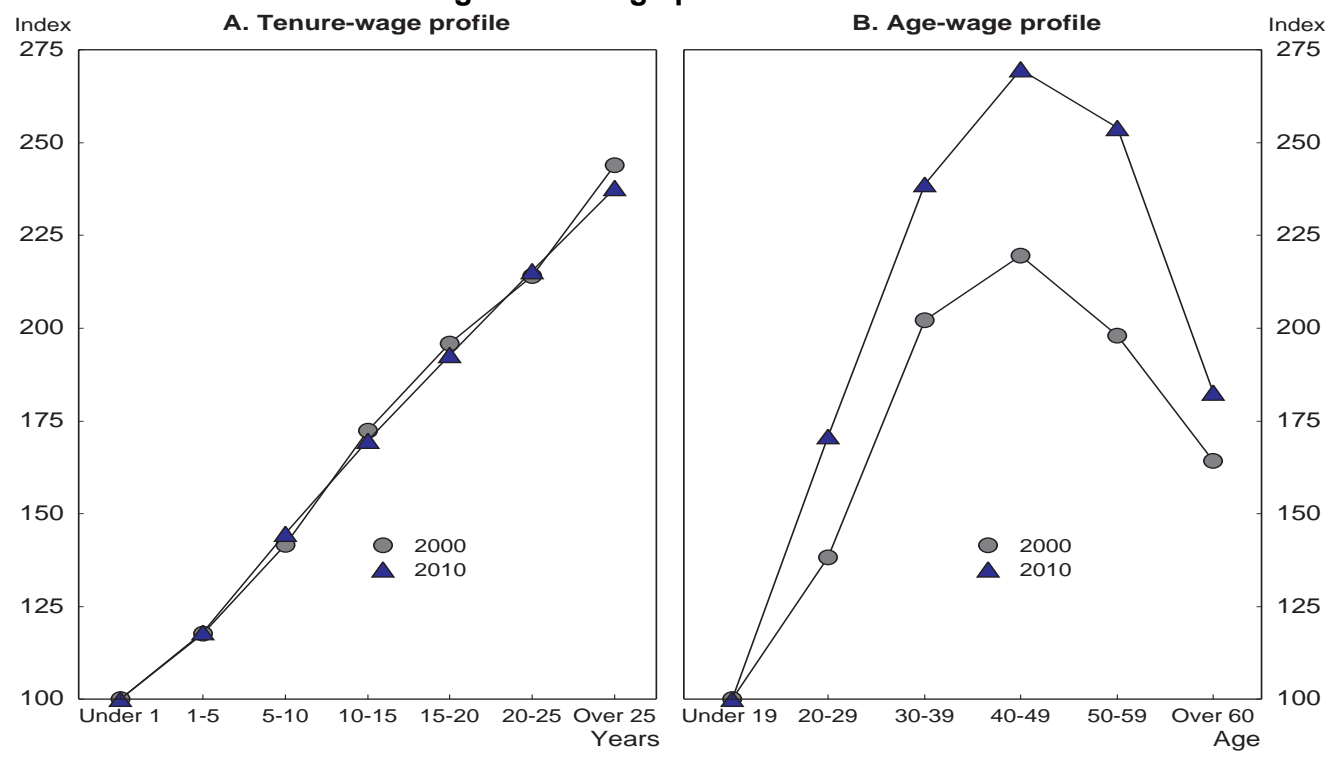

1. Wages for 19-year-olds and younger and for less than a year are set at 100 in each year.

Source: Ministry of Employment and Labour, Wage Structure Survey. 
22. In December 2011, the government announced the "Second Basic Employment Promotion Plan (2012-16) for the Aged" (Box 1). While the various subsidy programmes may have some impact, they have not prompted significant changes in labour practices and tend to have large deadweight costs (2008 OECD Economic Survey of Korea).

\section{Box 1. Second Basic Employment Promotion Plan (2012-16) for the Aged}

1. Strengthening support for inter-generational job-sharing:

$>$ Skilled middle-aged and old retirees will serve as mentors and instructors for young employees at 300 SMEs, and 1600 retired experts will be utilised as "on-site professors".

$>$ The job-sharing programme, which provides a subsidy of 7.2 million won per year to firms if they hire youth to fill vacancies that arise as middle-aged and older employees work shorter hours or receive training, will be promoted.

2. Expanding support for older workers to stay longer in their principal jobs:

$>$ Increasing subsidies for the wage-peak system.

$>$ Subsidies for extending the retirement age or re-employing aged workers will be differentiated based on the length of the extended employment period to encourage firms to keep older workers for a longer period.

$>$ The coverage of workplace surveys of retirement age schemes will be extended from those with 300 workers or more to those with 100 workers or more, to prepare for discussions on retirement age reform.

3. Strengthening support for retirement preparation and skills development:

$>$ It will be mandatory for large firms to provide a certain period of pre-retirement training to their middle-aged and older workers, who are forced to leave their jobs involuntarily.

$>$ Long-serving middle-aged and older workers will be granted the right to ask for unpaid educational leave of one year or less.

4. Expanding support for early re-employment and jobs for the aged:

$>$ Opportunities to participate in the Employment Success Package that links counselling, vocational training and job placement, and to receive on-the-job training at SMEs will be expanded.

$>$ Relevant training and funding to older people who want to start up their own business or return to farming or rural areas will be provided.

5. Promoting social contribution and talent-sharing activities:

6. Improving systems and infrastructure to cope with an aged society:

The retirement pension system will be further promoted to ensure old-age income security.

Key policy priorities to increase the use of older workers

23. Given Korea's demographic challenge, it is essential to expand continuous employment for older persons in firms. This requires a flexible employment and wage system based on ability rather than age, thus ensuring that older workers remain attractive to firms. According to the government's wage system survey, there is a close positive relationship between the flexibility of a firm's wage system and its employment of older workers. Another survey reported that $59 \%$ of workers are willing to accept a salary cut in exchange for an opportunity to work past the mandatory retirement age (Pacific Bridge, 2011). In sum, weakening the seniority-based wage system in favour of a performance-based system is essential. 
However, such an approach is unpopular with workers and has even led to strikes when introduced. ${ }^{6}$ Moreover, government subsidies to firms implementing the wage-peak system have had low take-up.

24. Additional government policies are needed in light of the difficulty of reaching a consensus between workers and firms to extend the employment of older workers. Among the OECD countries that allow firms to set a mandatory retirement age, Korea was one of the few that had not legislated a minimum age, leaving firms free to set the mandatory retirement age as low as they wish. The priority should be to set a minimum mandatory retirement age and gradually raise it to the pension eligibility age. Such an approach would put pressure on firms to adjust wages in line with productivity as workers grow older. The ultimate goal should be to abolish the right of firms to set mandatory retirement ages, thus helping to break down the link between seniority and wages. The 2008 Age Discrimination Act prohibits hiring based on age. The same logic should outlaw forced retirement based on age, which allows employment decisions to rest on a single criterion. Four OECD countries - the United States, Australia, Canada and the United Kingdom - have eliminated mandatory retirement. While this was done to improve human rights, the economic effects have been largely favourable (Klassen, 2011).

25. The abolition of mandatory retirement is often opposed on the grounds that it reduces employment opportunities for young people. However, this argument is based on the fallacy that an economy has a fixed number of jobs. In reality, limiting employment opportunities for some workers such as older people - simply decreases economic activity (OECD, 2006a). Indeed, the employment rates for younger and older workers across OECD countries are positively correlated and statistically significant (Figure 11).

26. It is also important to replace the mandatory retirement allowance with company pensions. The cost of the retirement allowance, which requires the payment of at least one month of wages for each year worked, rises sharply with seniority, thus increasing the expense of keeping older workers. The company pension system introduced in 2005 would provide better income security for retired workers, as well as reduce firms' incentives to retire older workers. Firms are now encouraged to establish either a defined benefit (DB) or a defined contribution (DC) system, based on an agreement with their workers. The company pension system now covers $9 \%$ of firms and $36 \%$ of employees, with two-thirds enrolled in DB plans. For employees who change jobs frequently, the government has created an individual retirement pension (IRP) with deferred taxation. In July 2012, the government launched a package of measures to revitalise retirement pensions: $i$ ) it put limits on the interim settlement of the retirement allowance, which employees use for major purchases; ii) departing employees are required to place their retirement allowance in an IRP; and iii) firms are allowed to adopt both DB and DC plans. This should accelerate the development of the company pension system, as it has been slowed by the difficulty of reaching an agreement between workers and firms on whether to introduce a DB (favoured by workers) or a DC system (favoured by firms). DC systems have the advantage of favouring pension and labour mobility for all workers. The government should encourage IRP accounts to promote pension portability.

\section{Encouraging labour force participation of discouraged youth}

27. The participation rate for youth (the 15-to-24-age group) declined from $37 \%$ in 1994 to $25 \%$ in 2010 , about half of the OECD average of $47 \%$. Although this was due in part to rising enrolment in tertiary education, it also reflects a mismatch problem, as the rising share of youth with tertiary education have difficulty in finding suitable employment. At the same time, Korean SMEs, which account for $99.9 \%$ of industrial firms and $87.7 \%$ of industrial employment, face a chronic workforce shortage that is partially

6. Standard Chartered's decision to introduce performance-based pay resulted in the longest strike ever in Korea's banking sector. This dispute was eventually settled by the introduction of a very generous early retirement programme, essentially buying off those with high salaries due to long service. 
filled by foreign workers. According to a 2011 government survey, 43\% of small firms said that they currently face a labour shortage and $40 \%$ expect to face one. The survey also reported that the labour shortage in small firms was attributable to the lack of qualified job applicants, the high expectations of job applicants and the low income and employee benefits offered by SMEs. The mismatch has been exacerbated as young people enter tertiary education to avoid being trapped in non-regular employment.

Figure 11. Employment rates of younger and older workers

Percentage of 55-59 year-olds and 20-24 year-olds in employment in $2010^{1}$

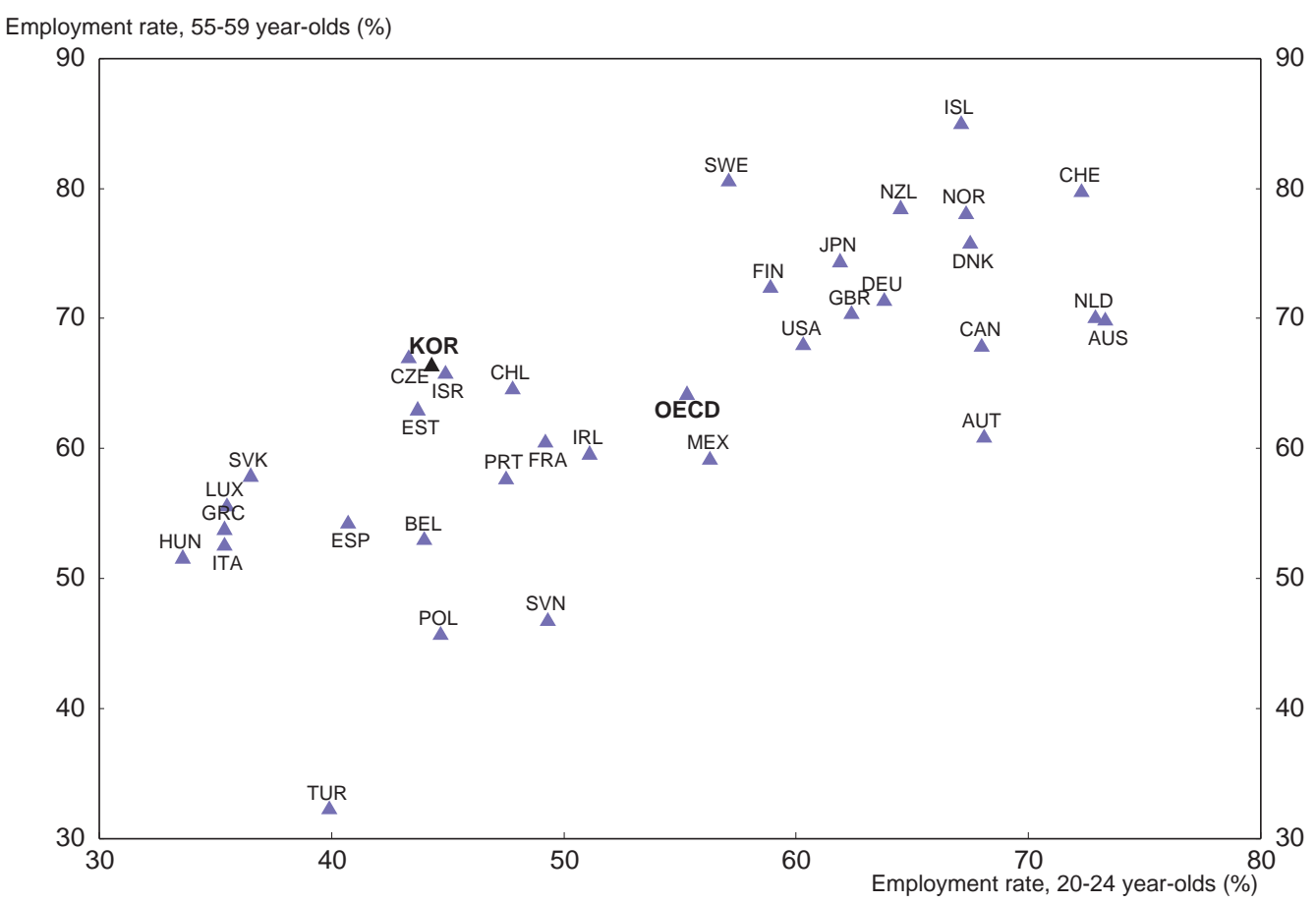

1. The correlation coefficient is 0.53 .

Source: OECD ELS Database.

28. It is essential to address the problem of overemphasis on tertiary education by improving vocational education, providing effective training courses that meet labour market needs, particularly for SMEs facing labour shortages, and improving access to employment services for career consulting and jobsearch assistance. Job training for unemployed youth is limited, as such training tends to be provided by firms. Meanwhile, the government's traditional training programmes aimed at youth concentrated on university graduates, while neglecting less educated youth, although the emphasis was shifted by several recent initiatives. Perhaps most important is the "New Start Project for Youth", which was launched in 2008 to provide in-depth and individually-customised assistance. It targets those with a high school education or less, the long-term unemployed and other disadvantaged youth, to improve their employability.

29. In 2011, the New Start Project was merged into the "Packaged Employment Service" aimed at low-income people. The Service combines career consulting, work experience and job placement services, while providing six months of living subsidies of up to 200000 won (about \$180) a month. Recipients can receive assistance for up to 12 months, divided into three stages from career guidance to job placement: 
- First stage: a course aimed at boosting participants' confidence and desire to work through individual counselling and career guidance. Each participant who completes the counselling and establishes an Individual Action Plan (IAP) is paid a 200000 won allowance.

- Second stage: participants either begin work experience or vocational training, based on their IAPs. Those with internships of three to five months in government-funded non-profit organisations are paid up to 760000 won a month (one-third of the average wage in the industrial sector). For those who work at SMEs, half of their wages up to 800000 won (\$725) are paid by the government for six months. If they are hired by the firm as regular workers at the end of the internship, a subsidy of 650000 won a month is paid for another six months. For participants needing training, vocational skill development accounts that pay up to two to three million won per person ( $\$ 1800$ to $\$ 2700)$ are offered.

- Third stage: participants are helped to find employment through intensive job-placement services, including accompanying them to interviews, organising company tours and providing information on job openings. Participants who obtain a job receive an allowance of up to 1 million won $(\$ 900)$.

30. The programme enrolled 20000 participants in 2011 (about $9 \%$ of the unemployed under the under the age of 30), of whom two-thirds were employed by the time they finished the training. In 2011, the government expanded the coverage to include other groups, such as the elderly and female family heads. The success of these employment support programmes depends on their acceptance by firms, suggesting a need for close links with the labour market. In addition, effective implementation of a standardised system of recognition of acquired skills is needed to improve employment prospects for youth. Overlapping qualification systems in the public and private sectors should be streamlined to respond to labour market demands.

31. As discussed below, reducing labour market dualism would improve the job prospects of youth, as well as women. This requires, in part, reducing employment protection. The experience of other OECD countries shows that a high level of employment protection for permanent workers hinders the integration of youth in the labour market (OECD, 2008). Moreover, dualism boosts job instability. Around 57\% of non-regular workers in Korea have worked less than one year in their current jobs, and only $22 \%$ more than three years. In contrast, only $25 \%$ of regular workers have worked less than one year, while $54 \%$ worked more than three years. In addition to the negative implication for wages, shorter tenure reduces the incentive for firms to invest in training non-regular workers. Indeed, the same study reported that only $2 \%$ of non-regular workers received firm provided training, compared to $15 \%$ for regular workers. The high share of workers receiving limited training slows human capital accumulation, with negative implications for their productivity and Korea's growth potential.

\section{Labour market policies to break down labour market dualism and promote social cohesion}

32. Korea is one of five OECD countries identified as having a high degree of inequality originating in the labour market (Koske et al., 2011). A key factor is the high share of non-regular workers - which includes fixed-term, part-time and atypical workers (such as those from temporary worker agencies). Regular workers are characterised by high wages, employment inflexibility, high employment protection and broad coverage by the social safety net and active labour market policies (Table 3 ). In contrast, nonregular workers face low wages, unstable employment, low employment protection and weak coverage by the social safety net and active labour market policies (Box 2). The share of temporary workers, who account for more than one-third of non-regular workers in Korea, was the fourth highest in the OECD area in 2011 (Figure 12). 
Table 3. Flexibility and security in the Korean labour market

\begin{tabular}{|c|c|c|c|c|c|}
\hline \multirow[b]{2}{*}{ Types of workers } & \multicolumn{2}{|c|}{ Flexibility } & \multicolumn{3}{|c|}{ Security } \\
\hline & $\begin{array}{l}\text { Numerical }^{1} \\
\text { flexibility }^{-}\end{array}$ & $\begin{array}{l}\text { Functional }^{2} \\
\text { flexibility }\end{array}$ & $\begin{array}{l}\text { Employment } \\
\text { protection }\end{array}$ & Social safety net & $\begin{array}{l}\text { Active labour } \\
\text { market policies }\end{array}$ \\
\hline $\begin{array}{l}\text { Regular workers in the } \\
\text { manufacturing sector } \\
\text { and/or in large } \\
\text { corporations }\end{array}$ & $\begin{array}{l}\text { Very low } \\
\text { flexibility }\end{array}$ & $\begin{array}{l}\text { Very low } \\
\text { flexibility }\end{array}$ & High & $\begin{array}{l}\text { Included in } \\
\text { coverage, albeit } \\
\text { ineffective }\end{array}$ & $\begin{array}{l}\text { Included in } \\
\text { coverage, albeit } \\
\text { inefficient }\end{array}$ \\
\hline $\begin{array}{l}\text { Non-regular workers in } \\
\text { the service sector and/or } \\
\text { SMEs }\end{array}$ & $\begin{array}{l}\text { High labour } \\
\text { mobility, low job } \\
\text { security }\end{array}$ & No flexibility & Very low & $\begin{array}{l}\text { Mostly excluded } \\
\text { from coverage }\end{array}$ & $\begin{array}{l}\text { Mostly excluded } \\
\text { from coverage }\end{array}$ \\
\hline
\end{tabular}

1. The ability of firms to adjust its labour inputs to accommodate changes in demand.

2. The ability of firms to deploy workers between tasks as demand for different types of labour changes.

Source: Koh et al., (2010).

Figure 12. International comparison of temporary employment

As a share of total employees in $2011^{1}$

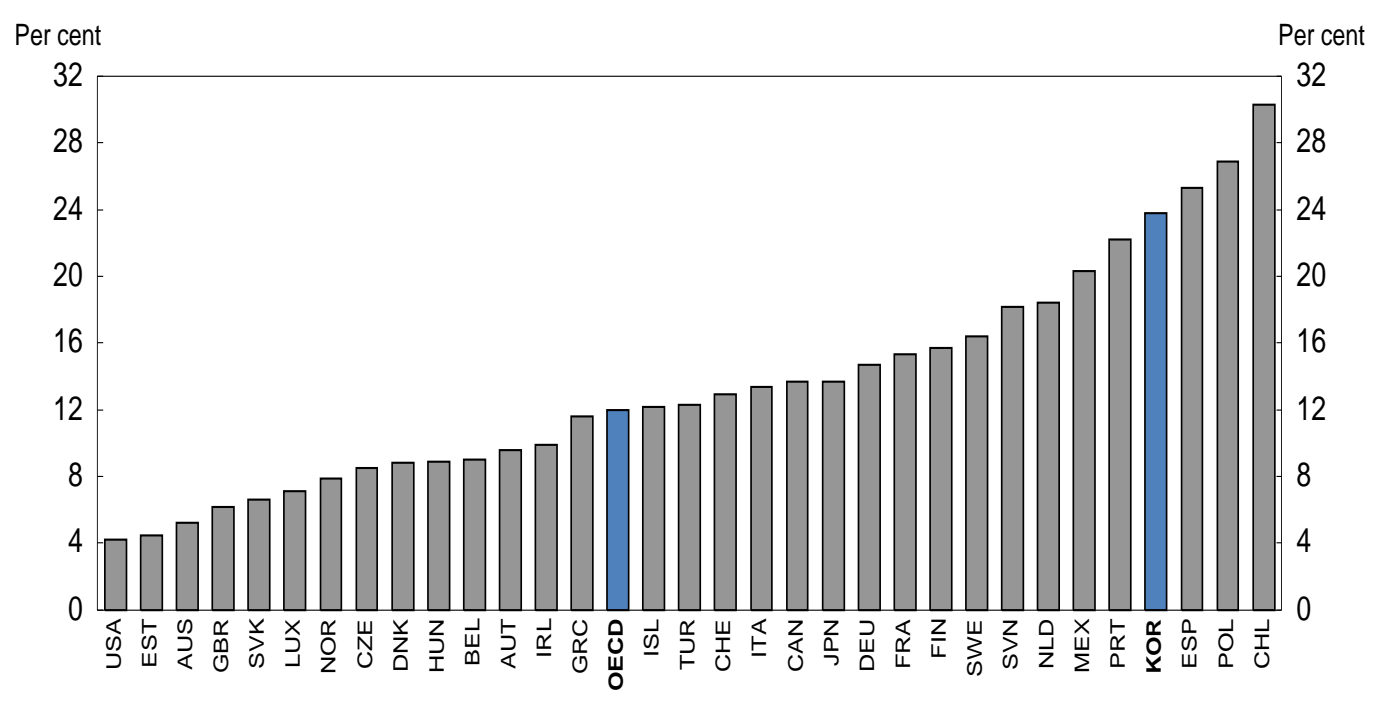

1 Temporary employees are defined as wage and salary workers whose job has a pre-determined termination date. For Korea, it includes only firms with a fixed-term contract, temporary agency workers and on-call workers (excluding double-counting).

Source: OECD Employment Outlook Database. 


\section{Box 2. Labour market dualism in Korea}

Non-regular workers - a category that includes temporary (i.e. those with fixed-term contracts), part-time and atypical workers, such as temporary agency workers - account for one-third of employees (Table 4). The largest component of non-regular employment is temporary workers at almost one-half of non-regular workers. Firms hire nonregular workers to reduce labour costs and to increase employment flexibility, given the difficulty and cost of laying off regular workers.

Table 4. Employed persons by status ${ }^{1}$

\begin{tabular}{|c|c|c|c|c|c|c|c|c|c|}
\hline \multirow[b]{3}{*}{ Year } & \multirow{3}{*}{$\begin{array}{l}\text { Wage } \\
\text { workers }\end{array}$} & \multirow{3}{*}{\multicolumn{2}{|c|}{$\begin{array}{l}\text { Non-regular } \\
\text { workers }\end{array}$}} & \multicolumn{6}{|c|}{ of which ${ }^{1}$} \\
\hline & & & & \multicolumn{3}{|c|}{ Temporary workers } & \multirow[b]{2}{*}{$\begin{array}{l}\text { Part-time } \\
\text { workers }\end{array}$} & \multicolumn{2}{|c|}{$\begin{array}{l}\text { Atypical } \\
\text { workers }\end{array}$} \\
\hline & & & & $\begin{array}{l}\text { With fixed- } \\
\text { term } \\
\text { contract }\end{array}$ & $\begin{array}{l}\text { With open- } \\
\text { ended contract, } \\
\text { expect job to } \\
\text { continue }^{2}\end{array}$ & $\begin{array}{c}\text { With open- } \\
\text { ended contract, } \\
\text { but could be } \\
\text { dismissed }^{3}\end{array}$ & & $\begin{array}{l}\text { Dispat- } \\
\text { ched }\end{array}$ & Others \\
\hline & Thousand & $\begin{array}{l}\text { Thou- } \\
\text { sand }\end{array}$ & $\begin{array}{l}\text { Per } \\
\text { cent }\end{array}$ & $\begin{array}{l}\text { Per } \\
\text { cent }\end{array}$ & $\begin{array}{l}\text { Per } \\
\text { cent }\end{array}$ & $\begin{array}{l}\text { Per } \\
\text { cent }\end{array}$ & $\begin{array}{l}\text { Per } \\
\text { cent }\end{array}$ & $\begin{array}{l}\text { Per } \\
\text { cent }\end{array}$ & $\begin{array}{l}\text { Per } \\
\text { cent }\end{array}$ \\
\hline 2003 & 14149 & 4606 & 32.6 & 52.2 & 5.4 & 7.9 & 20.2 & 2.1 & 34.3 \\
\hline 2005 & 14968 & 5483 & 36.6 & 49.8 & 5.5 & 10.7 & 19.0 & 2.1 & 32.6 \\
\hline 2007 & 15882 & 5703 & 35.9 & 44.4 & 9.7 & 8.1 & 21.1 & 3.1 & 35.7 \\
\hline 2009 & 16479 & 5754 & 34.9 & 48.9 & 3.0 & 9.1 & 24.8 & 2.9 & 36.8 \\
\hline 2011 & 17510 & 5995 & 34.2 & 44.5 & 5.7 & 7.3 & 28.4 & 3.3 & 37.2 \\
\hline
\end{tabular}

1. The sum of the categories of non-regular workers exceeds $100 \%$ due to double-counting.

2. Workers' whose term is not fixed and can be renewed regularly.

3. An employee could be dismissed, for example, due to seasonal factors, completion of a project or the return of an employee whom they were replacing.

Source: Statistics Korea, Survey on Economically Active Population.

A 2011 government labour survey shows that non-regular workers are disproportionately older, female, less educated, engaged in elementary work and employed in SMEs (Table 5):

- The proportion of non-regular workers is highest among older workers. In 2011, the over-60 age group accounted for only $7.8 \%$ of employees but $16.0 \%$ of non-regular workers (Panel A). In contrast, only $3.5 \%$ of regular workers were over 60.

- Female employees accounted for over half of non-regular workers, but only $37.1 \%$ of regular workers (Panel B).

- Non-regular workers tend to be less educated, as a quarter finished only middle school or less compared to $9.7 \%$ for regular workers (Panel C). On the other hand, most workers with tertiary degrees are regular workers, thus helping to fuel demand for university education.

- Almost one-half of non-regular workers were engaged in assembly and elementary work, compared to less than one-third of regular workers (Panel D). In contrast, only $18.1 \%$ were in management.

- There is significant variation between sectors. The share of non-regular workers is especially large in wholesale and retail trade and construction (Panel E).

- $\quad$ Non-regular workers are concentrated in firms with less than 300 employees (Panel F).

- Non-regular workers have shorter tenure, averaging around two years, compared to more than six years for regular workers (Panel G).

- Non-regular workers receive significantly less coverage by the social insurance system. Less than half of non-regular workers are covered by employees' pension and health insurance and employment insurance, compared to around four-fifths for regular workers (Panel $\mathrm{H})$. 


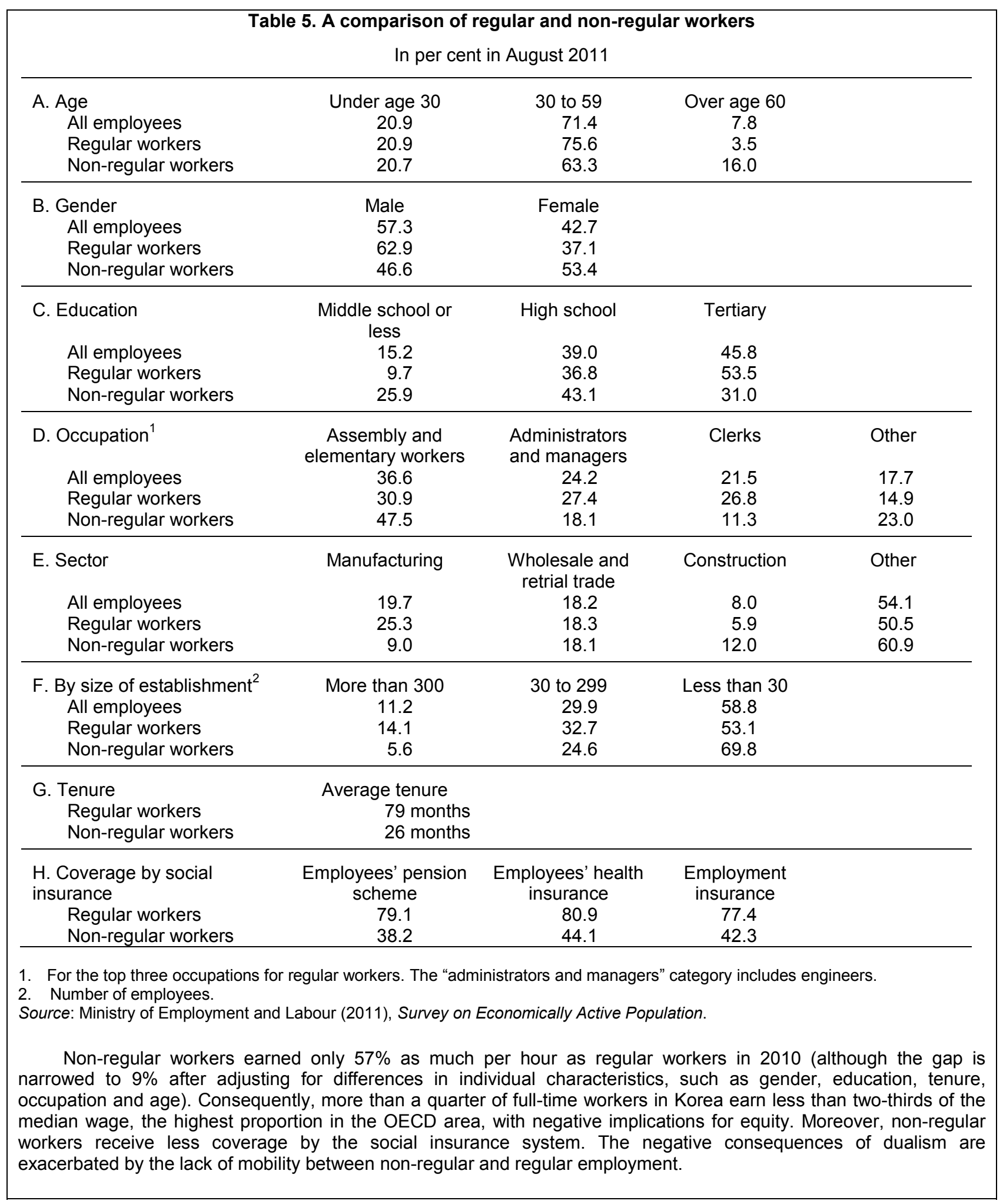


ECO/WKP(2013)60

\section{Factors explaining the high level of labour market dualism}

33. Korea's rapid integration in a globalised economy, particularly following the 1997 Asian crisis, intensified competition, prompting firms to reduce fixed costs, including labour, and pursue employment flexibility by hiring non-regular workers (Koh et al., 2010). Indeed, non-regular workers were paid only $57 \%$ as much as regular workers per hour in 2010 . According to a government survey, $32.1 \%$ of firms cited reducing costs as the most important reason for hiring non-regular workers (Table 6). Their lower wages are explained in part by productivity differences. However, the gap remains significant at $9 \%$, according to the government, after adjusting for workers' tenure, gender, age and educational attainment, suggesting that discrimination plays a role. Another study estimated the gap at 7\% (KDI, 2009), while the Korea Employers Federation estimated the productivity gap at $22 \%$ below regular workers, about half the gap in wages (KEF, 2006). If the wage gap were entirely explained by productivity differences, firms would have less reason to hire non-regular workers to reduce labour costs. Non-regular workers are primarily in fixedterm positions and work as substitutes for regular workers (Kim, 2010). In addition to lower hourly wages, the labour costs for non-regular workers are reduced another $6 \frac{1}{2}$ per cent by their relatively low participation in social insurance systems, which reduces firms' contributions. On top of this, non-regular workers receive fewer welfare benefits from firms. The savings on welfare costs adds up to $10 \%$.

Table 6. Reasons given by firms for hiring non-regular workers Percentages based on a government survey of firms

\begin{tabular}{|c|c|c|c|c|c|c|}
\hline & $\begin{array}{c}\text { Reduce } \\
\text { labour costs }\end{array}$ & $\begin{array}{c}\text { Increase } \\
\text { employment } \\
\text { flexibility }\end{array}$ & $\begin{array}{c}\text { Perform } \\
\text { peripheral } \\
\text { tasks }\end{array}$ & $\begin{array}{c}\text { Perform } \\
\text { short-term } \\
\text { tasks }\end{array}$ & $\begin{array}{l}\text { Other } \\
\text { reasons }\end{array}$ & Total \\
\hline All industries & 32.1 & 30.3 & 18.5 & 13.9 & 5.2 & 100.0 \\
\hline Manufacturing & 28.7 & 34.5 & 17.9 & 14.7 & 4.1 & 100.0 \\
\hline Non-manufacturing & 35.4 & 26.1 & 19.1 & 13.2 & 6.2 & 100.0 \\
\hline By firm size & . & & & & & \\
\hline Less than 30 & 35.5 & 28.9 & 15.8 & 13.2 & 6.6 & 100.0 \\
\hline $30-99$ workers & 28.5 & 27.6 & 18.7 & 18.2 & 7.0 & 100.0 \\
\hline 100-299 workers & 37.7 & 26.2 & 15.5 & 14.3 & 6.3 & 100.0 \\
\hline 300-499 workers & 34.3 & 29.4 & 19.6 & 12.7. & 3.9 & 100.0 \\
\hline More than 500 & 28.1 & 49.9 & 22.9 & 9.6 & 1.6 & 100.0 \\
\hline
\end{tabular}

Source: OECD (2007b).

34. Hiring non-regular workers to reduce labour costs is more important for small firms and those outside manufacturing. Nevertheless, the experience of Hyundai Motor demonstrates that it is important for large manufacturing firms as well. When the Supreme Court ruled in 2010 that Hyundai must grant regular status to a temporary worker, the company's 8200 temporary workers mobilised to demand similar treatment. Such a move would cost the company an extra 260 billion won ( $\$ 235$ million) in wages (Korea Labor Review, January-February 2011).

35. The second major reason for hiring non-regular workers is to increase employment flexibility (Table 6). The reforms adopted in the wake of the 1997 Asian financial crisis strengthened competition by reducing import barriers, liberalising restrictions on foreign direct investment inflows and upgrading competition policy (2000 OECD Economic Survey of Korea). Such reforms increased Korea's integration in the world economy, with imports' share of GDP doubling from a quarter in 1993 to one-half by 2008. These factors made employment flexibility a priority for firms, especially large ones, given the difficulty and cost of laying off regular workers, who receive relatively high employment protection as a result of government policies, business practices, social customs and labour unions (Koh et al., 2010). According to the Ministry of Employment and Labour, "Regular workers enjoy a high level of legal protection in Korea 
and managements' employment adjustment decisions often face strong opposition, which is still prevalent in the Korean labour market"?

36. The importance of non-regular workers as a buffer against cyclical shocks has become increasingly evident since the 1997 Asian financial crisis, as non-regular employment has become more closely correlated with economic cycles. In contrast, adjustment of regular workers lags behind economic cycles, reflecting the difficulty of dismissing permanent workers. Using non-regular workers as a buffer meant that women bore the brunt of the employment adjustment following the 2008 global financial crisis, as they are over-represented among non-regular workers. Moreover, the real wages of non-regular workers fell $1.5 \%$ between 2008 and 2010, while those of regular workers increased by $0.2 \%$. While non-regular workers are beneficial to firms, in part as they allow them to keep the regular workers in whom they have invested training, it creates equity problems as the low-paid non-regular workers are less covered by unemployment insurance and tend to withdraw from the labour force when they lose their job (Hwang, 2010).

37. A 2011 government survey found that slightly less than half of non-regular workers voluntarily accepted non-regular status (Table 7). Consequently, $52 \%$ of the 5.8 million non-regular workers - about 3 million employees - are involuntarily employed as non-regular workers, a group that is 3.5 times larger than the 0.85 million unemployed in 2011. Atypical workers, such as dispatched workers, are the least likely to voluntarily accept non-regular employment. The high share of non-regular workers is thus driven primarily by firms' need for employment flexibility and lower wage costs, rather than by workers' preferences. The workers who involuntarily work in non-regular employment accept it primarily to obtain immediate income. As noted above, non-regular workers tend to be older, less educated, employed in SMEs, have shorter tenure and work in the service sector (Table 5). In addition, women are overrepresented; $42 \%$ of female employees are in non-regular employment compared to $28 \%$ of males.

Table 7. Reasons given by non-regular workers for accepting non-regular employment

\begin{tabular}{|c|c|c|c|c|}
\hline & Total & $\begin{array}{c}\text { Temporary } \\
\text { workers }\end{array}$ & $\begin{array}{l}\text { Part-time } \\
\text { workers }\end{array}$ & $\begin{array}{l}\text { Atypical } \\
\text { workers }\end{array}$ \\
\hline Voluntary non-regular workers & 47.6 & 55.1 & 44.7 & 35.4 \\
\hline Satisfied with working condition & 44.4 & 49.5 & 35.3 & 40.4 \\
\hline To obtain job security & 23.2 & 30.7 & 3.5 & 17.2 \\
\hline To balance work with other activities ${ }^{1}$ & 19.0 & 14.1 & 43.5 & 14.1 \\
\hline To have more flexibility in work hours ${ }^{2}$ & 13.4 & 5.6 & 17.7 & 28.4 \\
\hline Involuntary non-regular workers & 52.4 & 44.9 & 55.3 & 64.6 \\
\hline To obtain immediate income & 76.5 & 74.6 & 68.3 & 83.5 \\
\hline Cannot find a desirable job & 13.0 & 15.4 & 12.7 & 10.3 \\
\hline To balance work with other activities ${ }^{1}$ & 7.8 & 8.4 & 15.1 & 3.0 \\
\hline
\end{tabular}

1. Includes balancing work with family responsibilities and educational and vocational training, as well as to accumulate job experience.

2. This category includes obtaining performance-based pay.

Source: Statistics Korea.

38. The negative consequences of dualism are exacerbated by the lack of mobility between nonregular and regular employment. According to one government report, "The severity of the non-regular work issue in Korea is derived from the fact that non-regular workers find it very difficult to escape from the trap of non-regular work" (Chung, 2008). In other words, non-regular employment is unlikely to be a stepping stone into regular jobs (KDI, 2009), in contrast to many other OECD countries, where a large share of temporary workers moves into permanent employment (OECD, 2006b). One study reported that only $10 \%$ of non-regular workers a year on average became regular workers between 2003 and 2008 (KDI,

7. A response provided to an OECD questionnaire. 
2009). Transition from non-regular status to regular status was much lower in 2008-09 than it was a decade earlier (Chang, 2011). The probability of making the transition to regular status tends to be higher for younger male workers with longer tenures in large manufacturing firms (Kim, 2009). The movement from regular to non-regular employment is even smaller, as regular workers are reluctant to lose their advantages.

\section{The impact of the 2007 labour law reform}

39. After five years of discussion with the social partners, the government reformed the labour law in 2007 to prohibit unreasonable discrimination against fixed-term, part-time and temporary agency workers. ${ }^{8}$ Between July 2007 and February 2012, 2443 cases affecting 5262 workers have been filed with the Labour Relations Commission. Some workers facing discrimination have reportedly chosen not to bring their cases to the Labour Relations Commission for fear of reprisals, prompting the government to further reform the labour law. ${ }^{9}$ Nevertheless, a considerable number of firms have endeavoured to reduce discrimination against non-regular workers since the 2007 reform. This may have contributed to the slight narrowing in the wages of non-regular workers from $85 \%$ regular workers in 2007 to $91 \%$ (after adjusting for differences in individual characteristics, such as gender, education, tenure, occupation and age) in 2010.

40. In addition, the 2007 reform limited the length of employment for non-regular workers to a maximum of two years, with some exceptions, to avoid their "excessive use". According to a government survey of fixed-term workers whose contracts expired after working more than 18 months:

- $22 \%$ were converted to non-fixed-term contract workers. ${ }^{10}$ However, most firms reportedly did not change the salaries of the converted workers to the level of other regular workers, thus creating a third category in the workplace - regular workers without the wages and benefits of regular workers (Kwon, 2010). According to the Korea Federation of Trade Unions, the nonregular workers converted to regular status are paid two-thirds as much as other regular workers.

- $32 \%$ were considered non-fixed-contract workers, regardless of whether their employers took action to change their contract.

- $45 \%$ did not have their contracts renewed. As expected, the limit on temporary workers led to large-scale termination of contracts, as many firms opted to end the contracts of those nearing the two-year limit rather than elevate them to regular status (Korea Labor Review, NovemberDecember 2011).

41. The $6 \%$ increase in the number of non-regular workers between 2006 and 2011 indicates that the 2007 reform has not reduced the number of non-regular workers, even though their share of employment has fallen, and the labour market remains severely segmented. At the same time, there has been a

8. The reform, which amended the Fixed-Term Employment Act and the Act on the Protection, etc. of Temporary Agency Workers, took effect in July 2007.

9. To address this problem, the Fixed-Term Employment Act and the Act on the Protection, etc. of Temporary Agency Workers have been amended. Under the revised law, which took effect in August 2012, labour inspectors have to encourage employers to correct any discrimination that may be found, even if there is no request from the workers. If the employers fail to remedy the situation, the case should be reported to the Labour Relations Commission.

10. The government has 341 thousand non-regular workers, of which about half are fixed-term workers. It announced in December 2011 that it intends, in principle, to give indefinite contracts to those who are engaged in permanent and full-time work. The number of eligible employees is estimated at 97 thousand (Korea International Labour Foundation, 2011). 
diversification in the types of non-regular workers, away from fixed-term contracts and towards part-time and atypical work. ${ }^{11}$ In sum, the 2007 reform has helped the fixed-term workers who are now considered to be non-fixed-term workers. The key question is the outcomes for the $45 \%$ whose contracts are terminated before the two-year limit is reached. If they are not hired by another firm or find self-employment, the 2007 reform would boost unemployment while lowering the employment rate. Even if total employment is maintained, the 2007 reform substantially increases job instability for the largest group of non-regular workers. In other words, the increased transition to regular status for some fixed-term workers comes at the cost of greater job instability for a larger share of fixed-term workers.

\section{Problems associated with the high share of non-regular workers}

42. Increasing the share of regular workers would have the advantages of promoting job stability and firm-provided training, while enhancing the development of social insurance systems. On the other hand, the persistently high share of non-regular workers benefits firms, in terms of labour costs and flexibility, and accommodates workers who prefer more flexible work patterns. However, as noted above, dualism reduces the incentive for firms to invest in on-the-job training for a significant portion of their employees. In addition, it has negative effects on social cohesion, which are discussed in this section.

43. First, it increases wage disparity and relative poverty. As noted above, non-regular workers are paid about half as much as regular workers, due in part to discrimination. The fact that most non-regular workers perform almost the same tasks as regular workers and work the same hours makes the wage differential problematic (Kim, 2010). Indeed, more than a quarter of full-time workers in Korea earn less than two-thirds of the median wage, the highest share in the OECD area, thus fuelling inequality. The lower wages are explained in part by the shorter tenure of non-regular workers, as noted above, which puts them at a disadvantage given the steep earnings-tenure profile (Figure 10). The low wages of non-regular workers has been a key factor in the rise in income inequality and relative poverty. As measured by the Gini coefficient, inequality was on an upward trend until 2009 (Figure 13), when it reached the OECD average. Meanwhile, relative poverty - the share of the population living on less than half of the median income - rose to $15 \%$ in 2008, the seventh highest in the OECD area (Panel B). According to a recent study (Lee, 2011), 20\% of non-regular workers are in relative poverty. In addition, a 2009 study found that the rate of poverty among the working-age population was only $1.5 \%$ for regular workers, as compared to $13.5 \%$ for temporary employees and $26.3 \%$ for day labourers (Figure 14 ).

44. Second, equity concerns are exacerbated by the low share of non-regular workers covered by social insurance, as noted above. The legal framework requires nearly all workers to be covered by the social insurance system, including the EIS. ${ }^{12}$ In practice, however, there is a large gap between the statutory coverage and actual coverage, with many non-regular workers excluded (Korea Labor Review, March-April 2009). Indeed, in 2011, only $38 \%$ and $44 \%$ of non-regular workers were enrolled in the NPS and the National Health Insurance (NHI), respectively, at their workplace, while $42 \%$ were enrolled in the EIS (Table 5). Gaps in coverage thus reflect weak compliance, particularly among small firms. While the share of unemployed receiving benefits has risen from $7 \%$ in 2000 to over $30 \%$ in 2007 (Figure 15), the limited coverage of the EIS undermines its effectiveness, including in its other activities, such as paying for training and maternity leave. Weak coverage helps to explain why public social spending was only $9.6 \%$ of GDP in 2009.

11. The falling share of fixed-term workers and the rising share of other categories has slightly increased the average tenure of non-regular workers from 2.1 years in 2006 to 2.3 years in 2011.

12. The EIS in principle now covers all wage and salary earners in all establishments, except: $i$ ) part-time workers working less than 60 hours a month (or 15 hours a week); ii) government officials and employees subject to the Private School Teachers' Pension Act; and iii) workers over age 65. 
Figure 13. Inequality has been increasing in Korea ${ }^{1}$
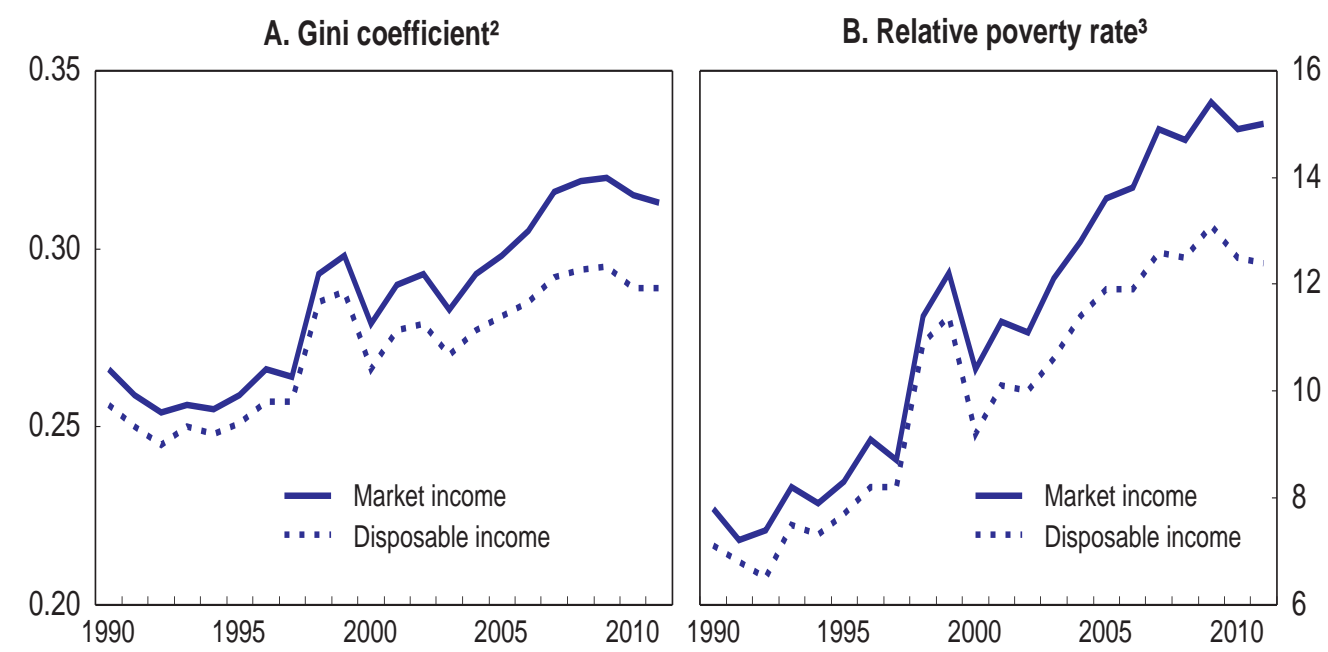

1. For urban households with at least two persons.

2. The Gini coefficient can range from 0 (perfect equality) to 1 (perfect inequality).

3. Relative poverty is defined as the share of the population that lives on less than half of the median income.

Source: Statistics Korea.

45. Entrenched dualism creates conflicts between regular workers (the insiders) and non-regular workers (the outsiders). Many unions do not allow non-regular workers to join and few seek to represent them, given that non-regular workers are substitutes for regular workers (Kim, 2010) and thus pose a risk to the job security of union members. Enterprise-based collective bargaining agreements thus, in general, do not cover non-regular workers. Companies with unions have higher shares of non-regular workers, suggesting that they are particularly valued for employment flexibility. Including non-regular workers in unions may help reduce inequality between regular and non-regular workers (Choi et al., 2012).

Figure 14. Poverty rate among the working-age population in 2006 by employment status ${ }^{1}$

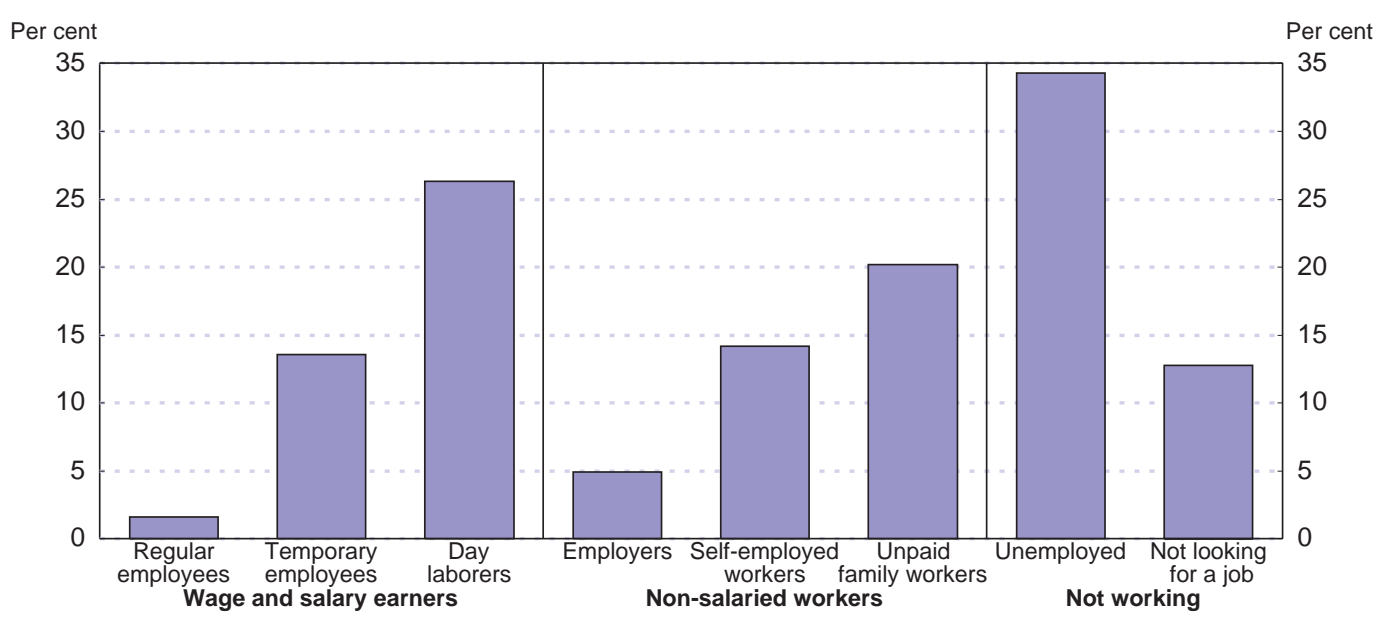

1. The poverty rate of the entire sample was $11.1 \%$.

Source: No et al., (2009). 
Figure 15. Coverage of unemployment insurance

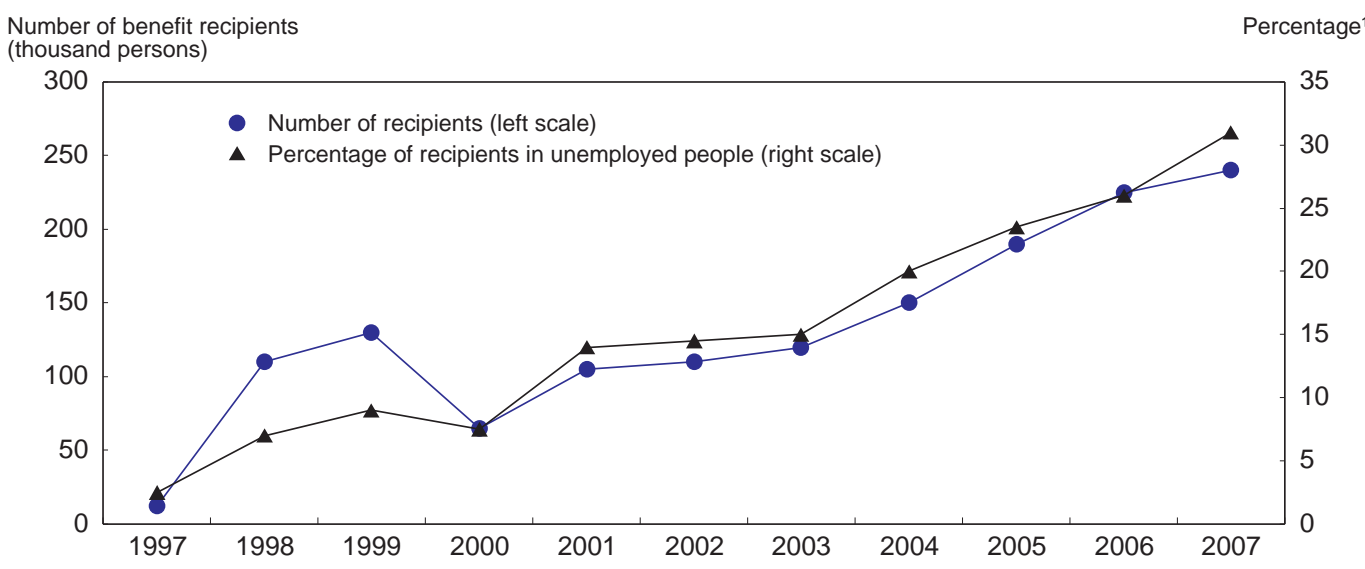

$1 . \quad$ As a share of total unemployed.

Source: Korea Labor Review, March-April, 2009.

\section{Policies to address labour market dualism}

46. Five years after the labour law reform, the share of non-regular workers remains high at one-third and job instability has increased. The government announced legislation in 2009 , which is still pending, to relax the 2007 reform by extending the maximum length of employment for fixed-term workers from two to four years. Such a reform would reduce job instability by lowering the turnover of fixed-term workers and the concentration of workers in more vulnerable types of non-regular employment. In addition, the government proposed an increase in the number of sectors and job categories in which temporary worker agencies are allowed to operate, given criticism from firms that current laws are too restrictive (KEF, 2011). The government should replace the "positive-list system", which limits such workers to certain occupations and industries, to a "negative-list system", which allows them in general, except in certain cases. Although lengthening the limit for using non-regular workers will benefit firms and promote employment stability, it will not address the dualism problem.

47. The government announced in September 2011 the "Comprehensive Non-regular Workers Initiative" to address dualism, primarily by strengthening the social safety net and enhancing equal treatment for non-regular workers:

i. Subsidising SMEs' contributions to social insurance systems to expand the coverage of their employees, including non-regular workers. Subsidies, set at one-third of the contributions to the EIS and NPS, will be given for employees who work at least 15 hours a week in a firm with fewer than five workers and earn no more than $120 \%$ of the minimum wage.

ii. Strengthening employment conditions, in part by better enforcing the minimum wage and by broadening the coverage of social insurance to include special types of employment, such as delivery vehicle drivers.

iii. Expanding vocational training opportunities for non-regular workers and promoting their transition to regular employment.

iv. Upgrading the inspection of labour conditions to encourage balanced treatment of regular and nonregular workers. 
While this initiative will help improve conditions for non-regular workers, breaking down dualism requires a comprehensive approach that weakens the incentives that encourage firms to hire non-regular workers, notably by relaxing employment protection for regular workers, expanding the social insurance coverage of non-regular workers by improving compliance and increasing training opportunities to enhance their employment prospects.

\section{Relax employment protection}

48. A key is to relax effective employment protection for regular workers to lower its cost so that firms can achieve their desired flexibility without depending as much on non-regular workers. Although Korea has promoted labour market flexibility since the 1997 Asian crisis, the OECD index of employment protection for regular workers in 2008 was 2.3, compared to the OECD average of 2.1. Moreover, it was far above countries such as the United States (0.6), Canada (1.2) and the United Kingdom (1.2) ${ }^{13}$ Recent OECD research shows that increasing employment protection has a significantly negative impact on GDP per capita, with no conclusive impact on total labour income equality (OECD, 2012a).

49. Moreover, employment protection for regular workers is exacerbated by its ambiguity. The 1998 revision of the labour law to allow collective dismissals for "urgent managerial reasons" has not sufficiently enhanced flexibility in practice, in part, due to certain requirements. In particular, firms must exhaust "all means" to avoid dismissals on economic grounds and discuss proposed dismissals for at least 50 days with workers in an effort to avoid them. In addition, for dismissals based on "managerial reasons", the firms must send a report to the Minister of Employment and Labour 30 days in advance, which includes the reason for dismissal, issues discussed with worker representatives, and a dismissal schedule. The unpredictability of the strong procedural requirements boosts the cost and uncertainty for firms, thus discouraging them from hiring regular workers. Indeed, international evidence suggests that the creation of temporary jobs is a common response by firms to high costs of reducing permanent jobs (Kahn, 2010). Changing the labour law to accelerate and simplify the procedures would enhance employment flexibility. In addition, reducing uncertainty by clearly specifying the compensation required for dismissed workers in Korea would increase predictability. In 2008, 22 OECD countries required payments for dismissed workers, ranging from eight weeks of salary to 20 months for a worker with 20 years of tenure.

\section{Expand social security insurance coverage}

50. The liberalisation of employment protection should be accompanied by increased coverage of non-regular workers by workplace-based social insurance systems. Many non-regular workers and their firms choose not to participate in social insurance schemes, given the high financial burden and frequent job changes. While the coverage of social insurance is increasing, further efforts to ensure compliance with social insurance premium payments, notably at small firms, are needed. Such measures would narrow the gap in labour costs between regular and non-regular workers, thus reducing incentives to hire non-regular workers, while improving their welfare. Moreover, having the National Tax Service collect social insurance contributions would increase compliance.

13. The OECD index of the strictness of employment protection legislation for regular employment covers eight indicators related to the procedures involved in individual dismissal, such as the prior notification requirement, severance pay provision, and remedial measures for an unfair dismissal. It runs from 0 (least restrictive) to 6 (most restrictive). 


\section{Increase opportunities for vocational training}

51. It is important to increase training opportunities for non-regular workers as firms invest less in their training. Expanded vocational training and career consultation outside firms would enhance the employment prospects of non-regular workers and facilitate their transition to regular status. Indeed, one study reported that the probability of making the transition from non-regular to regular jobs is significantly higher for non-regular workers who attend training programmes (KDI, 2009). In 2011, the "My Work Learning Card System", an individual training account that was available only to unemployed persons, was extended to non-regular workers to expand their training opportunities.

\section{Conclusion}

52. Korea's economic performance over the past 50 years has been outstanding. However, continuing the convergence to the highest-income countries is increasingly challenging as Korea enters a period of population ageing that is exceptionally rapid while per capita income is still relatively low. In addition, economic policy will have to place greater emphasis on environmental sustainability and achieving inclusive growth to promote social cohesion. Sustaining the convergence process requires labour market reforms to limit falls in labour inputs in the face of demographic headwinds. In addition, recent OECD research shows that policies that break down labour market dualism reduce income inequality while boosting economic growth (OECD, 2012a). Resolving these problems requires a comprehensive approach that is summarised in Box 3 .

Box 3. Summary of recommendations to enhance growth and social cohesion through labour market reform

\section{Encouraging labour market participation of women, elderly and youth}

- Encourage better work-life balance, in part by expanding flexibility in working hours and reducing them, lengthening maternity and paternity leave and encouraging their take-up by increasing the benefits for parental leave and reserving part of the leave time for the exclusive use of fathers.

- Increase the availability of affordable, high-quality childcare.

- $\quad$ Reduce labour market dualism to create better job opportunities for women and young people.

- Encourage greater use of flexible employment and wage systems to promote the continuous employment of older workers, while expanding and upgrading lifelong learning and training opportunities to improve their job prospects.

- Set a minimum mandatory retirement age and gradually increase it with an aim of eventually abolishing mandatory retirement, while phasing out the retirement allowance by further expanding company pensions.

- $\quad$ Ensure better access to comprehensive employment support programmes to encourage youth to work.

\section{Reforms to reduce labour market dualism}

- $\quad$ Reduce employment protection in practice for regular workers so that firms can realise adequate employment flexibility without relying as much on non-regular workers.

- $\quad$ Expand the coverage of non-regular workers by workplace-based social insurance systems, notably by improving compliance, to improve their welfare and reduce the cost advantages of hiring non-regular workers.

- Increase training and career consultation to enhance employability of non-regular workers and their transition to regular employment.

- Revise the 2007 non-regular law, which is increasing employment instability and leading to a concentration of nonregular workers in more vulnerable types of employment, by extending the time limit on fixed-term contracts.

- Relax regulations on temporary agency workers by moving from a positive-list system to a negative list. 


\section{Bibliography}

Cho, J. and J. Keum (2009), "Dualism in Job Stability of the Korean Labour Market: The Impact of the 1997 Financial Crisis", Pacific Economic Review, No. 14 (1).

Chang, J. (2011), "Labor Market Dualism and Social Insurance Coverage in Korea", paper presented at a conference, "Welfare States' Response to Labor Market Dualism and The Working Poor", 11 December, Seoul.

Choi, S., S. Kim and R. Freeman (2012), Hard Work and Human Capital: Korea in the New Global Economy, Korea Development Institute, Seoul (forthcoming).

Chung, H. (2008), "Follow-up to the Non-Regular Work Law and Related Key Programs in 2008", Ministry of Employment and Labor.

D'Addio, F. and M. Mira d'Ercole (2005), "Trends and Determinants of Fertility Rates in OECD Countries: The Role of Policies", OECD Social, Employment and Migration Working Papers, No. 6, OECD, Paris.

Grubb, D., J. Lee and P. Tergeist (2007), "Addressing Labour Market Duality in Korea", OECD Social, Employment and Migration Working Papers, No. 61, OECD, Paris.

Hwang, S. (2010), "Global Financial Crisis and the Labor Market", in Economic Crisis and Employment, edited by K. Hwang, Y. Yoon, S. Cho, B. Jun, G. Park and J. Ahn, Korea Labor Institute, Seoul.

Hyundai Research Institute (2010), "The Solution to Dissolve the Gap Between the Desired Number of Children and the Number of Children Born", VIP Report, 3 August (in Korean).

Jaumotte, F. (2003), "Labour Force Participation of Women: Empirical Evidence on the Role of Policy and Other Determinants in OECD Countries", OECD Economic Studies, No. 37, OECD, Paris.

Kahn, L. (2010), "Labor Market Policy: A Comparative View on the Costs and Benefits of Labor Market Flexibility”, CESIFO Working Papers, No. 3140.

Kim, Y. (2009), Research on Labour Mobility of Non-Regular Workers, Chapter 5 in Korea Development Institute Research Paper, No. 2009-03, Seoul.

Kim, J. (2010), “A Comparison of Non-Regular Employment in Korea and Japan: Nature, Difference, and its Possible Reasons", Evolutionary and Institutional Economics Review, No. 6 (2).

Kim, J. (2011), "Women's Career Disconnect and Re-entry into the Labor Market”, Labour issues in Korea 2010, edited by K. Bae, Korea Labour Institute, Seoul.

Kim, H. and S. Hwang (2009), "The Need for Work Sharing to Achieve Work-Life Balance, and Its Direction”, Labor Issues in Korea 2009, edited by M. Jun, Korea Labor Institute, Seoul.

Klassen, T. (2011), "New Policies for Korea's Aging Labor Force: The Role of Contractual Mandatory Retirement", Issue Paper No. 115, Korea Labor Institute, Seoul.

Koh, Y., S. Kim, C. Kim, Y. Lee, J. Kim, S. Lee and Y. Kim (2010), "Social Policy", in The Korean Economy: Six Decades of Growth and Development, edited by I. SaKong and Y. Koh, Korea Development Institute, Seoul.

Korea Development Institute (KDI) (2009), Study on Non-regular workers, Seoul (in Korean). 


\section{ECO/WKP(2013)60}

Korea Employers Federation (2006), 2006 Industrial Relations and Labor Market of Korea, Seoul.

Korea Employers Federation (2011), Major Statistics of Economy and Labor Market of Korea, Seoul.

Korea International Labour Foundation (2011), “Government's Initiative to Improve Employment of Nonregular Workers in Public Sector", Labor Today, 12 December.

Korea Labor Review (various issues), International Labour Foundation, Seoul.

Koske, I. J. Fournier, and I. Wanner (2011), "Less Income Inequality and More Growth - Are They Compatible?: Part 2. The Distribution of Labour Incomes", OECD Economics Department Working Papers, No. 925, OECD, Paris.

Kwon, H. (2010), “Temp-to-Perm Transition? Recent Legislation on Fixed-Term Employment and Firm's Choice”, Labor Issues in Korea 2009, edited by M. Jun, Korea Labor Institute, Seoul.

Lee, B. (2011), "Labour-market characteristics and poverty dynamics of the working poor in Korea", Labor Issues in Korea 2010, Korea Labor Institute, Seoul.

Ministry of Employment and Labour (2010), National Employment Strategy 2020, Seoul.

Ministry of Employment and Labour (2011), Survey on Economically Active Population, Seoul (in Korean).

No, D. et al., (2009), "Study on the Reform of Activation Policies in Korea", Korea Institute for Health and Social Affairs, Seoul (in Korean).

OECD (2000), OECD Economic Survey of Korea, OECD, Paris.

OECD (2006a), Ageing and Employment Policies, OECD, Paris.

OECD (2006b), Employment Outlook, OECD, Paris.

OECD (2007a), Jobs for Youth: Korea, OECD, Paris.

OECD (2007b), OECD Economic Survey of Korea, OECD, Paris.

OECD (2008), OECD Economic Survey of Korea, OECD, Paris.

OECD (2010), OECD Economic Survey of Korea, OECD, Paris.

OECD (2011), Doing Better For Families, OECD, Paris.

OECD (2012a), Going for Growth 2012, OECD, Paris.

OECD (2012b), OECD Economic Survey of Korea, OECD, Paris.

OECD (2012c), OECD Education at a Glance 2012, OECD, Paris.

OECD (2012d), OECD Employment Outlook 2012, OECD, Paris.

OECD (2013), Going for Growth 2013, OECD, Paris.

Pacific Bridge (2011), “Korean Workers Willing to Work Under Salary Peak System”, 9 June. 
ECO/WKP(2013)60

\section{WORKING PAPERS}

The full series of Economics Department Working Papers can be consulted at www.oecd.org/eco/workingpapers/

1067. Education reform in Korea

(June 2013) by Randall S. Jones

1066. Belgium: enhancing the cost efficiency and flexibility of the health sector to adjust to population ageing

(June 2013) by Stéphane Sorbe

1065. Italy and the euro area crisis: securing fiscal sustainability and financial stability (June 2013) by Oliver Denk

1064. Policy implementation in Italy: legislation, public administration and the rule of law (June 2013) by Paul O’Brien

1063. Greening growth in Luxembourg

(June 2013) by Nicola Brandt

Vers une croissance plus verte en Luxembourg

(juin 2013) par Nicola Brandt

1062. The post-crisis narrowing of international imbalances-cyclical or durable?

(June 2013) by Patrice Ollivaud and Cyrille Schwellnus

1061. Restructuring welfare spending in Slovenia

(June 2013) by Rafał Kierzenkowski

1060. The economics of civil justice: new cross-country data and empirics

by G. Palumbo; G. Giupponi; L. Nunziata and J. Mora-Sanguinetti (forthcoming)

1059. Banks' restructuring and smooth deleveraging of the private sector in Slovenia

(June 2013) by Olena Havrylchyk

1058. Assessing the efficiency of welfare spending in Slovenia with data envelopment analysis

(June 2013) by Matevz Hribernik and Rafał Kierzenkowski

1057. Policy determinants of school outcomes under model uncertainty: evidence from South Africa (June 2013) by Thomas Laurent, Fabrice Murtin, Geoff Barnard, Dean Janse van Rensburg, Vijay Reddy, George Frempong and Lolita Winnaar

1056. Improving education quality in South Africa

(June 2013) by Fabrice Murtin

1055. The 90\% public debt threshold: the rise and fall of a stylised fact

(June 2013) by Balázs Égert

1054. Challenges to sustain Poland's growth model

(June 2013) by Balázs Égert and Rafał Kierzenkowski

1053. Reforming agriculture and promoting Japan's integration in the world economy 
(May 2013) by Randall S. Jones and Shingo Kimura

1052. Inequality and poverty in the United States: public policies for inclusive growth (May 2013) by Oliver Denk, Robert Hagemann, Patrick Lenain and Valentin Somma

1051. Fiscal federalism and its impact on economic activity, public investment and the performance of educational systems (May 2013) by Hansjörg Blöchliger, Balázs Égert and Kaja Fredriksen

1050. Restoring Japan's fiscal sustainability

(May 2013) by Randall S. Jones and Satoshi Urasawa

1049. Measuring total factor productivity at the firm level using OECD-ORBIS

(May 2013) by Peter Gal

1048. A projection method for public health and long-term care expenditures (June 2013) by Christine de la Maisonneuve and Joaquim Oliveira Martins

1047. $R \& D$, patenting and growth: the role of public policy (May 2013) by Ben Westmore

1046. Knowledge-based capital, innovation and resource allocation (May 2013) by Dan Andrews and Chiara Criscuolo

1045. Reforms for a Cleaner, Healthier Environment in China (April 2013) by Sam Hill

1044. Making the tax system less distortive in Switzerland (April 2013) by Andrés Fuentes

1043. The determinants of informality in Mexico's states (April 2013) by Sean M. Dougherty and Octavio Escobar

1042. Legal reform, contract enforcement and firm size in Mexico (April 2013) by Sean M. Dougherty

1041. Improving the economic situation of young people in France (April 2013) by Hervé Boulhol Améliorer la situation économique des jeunes en France (avril 2013) par Hervé Boulhol

1040. Improving employment prospects for young workers in Spain (April 2013) by Anita Wölfl

1039. Youth labour market performance in Spain and its determinants - a micro-level perspective (April 2013) by Juan J. Dolado, Marcel Jansen, Florentino Felgueroso, Andres Fuentes and Anita Wölfl 